\title{
THE USE OF COOPERATIVE LEARNING TO IMPROVE STUDENTS' ABILITY IN READING COMPREHENSION IN MTS NURUL BAROKAH 2017
}

\author{
by \\ Ai Munawaroh \\ English Education Study Program, Faculty of Education and Teacher Training, \\ Suryakancana University \\ aimunawaroh299@gmail.com
}

\begin{abstract}
This paper reports a study of using cooperative learning to improve Students' ability in English reading comprehension of recount text. Because reading still becomes one of the problems which students face at school including Secondary School. Cooperative learning is one of the several methods which gives much opportunity for students in group with various abilities for comprehending of recount text. The aims of this study are to investigate use of cooperative learning and to find out the students' response of using cooperative learning for improving students' ability in English reading comprehension. This study applied mix method design by using triangulation by one group pre-test and post-test design. The quantitative data was obtained by students' score in English reading pre-test and post-test of recount text. Meanwhile, the qualitative data were obtained from classroom observation and interview. The study was conducted at one of the Islamic Junior High Schools in Cianjur which involved 24 students in eighth grade. The findings showed the hypothesis testing proved that $t_{\text {count }} \geq t_{\text {table }}$ $14,29 \geq 1.714$. Therefore, the null hypothesis was rejected. It meant, the use of cooperative learning could improve students' ability in English reading comprehension. Another finding also showed students' responses were positive. They responded that cooperative learning is more enjoyable. Furthermore, it helps them in understanding recount text and also it could be applied as one of the teaching reading to be implemented in Secondary School.
\end{abstract}

Key words: Reading, Reading Comprehension, Cooperative Learning and Recount Text

\begin{abstract}
ABSTRAK
Karya ilmiah ini melaporkan tentang sebuah penelitian mengenai penggunaan pembelajaran kooperatif untuk meningkatkan kemampuan pemahaman membaca siswa mengenai teks recount. Karena membaca masih menjadi salah satu masalah yang para siswa hadapi di sekolah termasuk di sekolah menengah. Pembelajaran kooperatif merupakan salah satu metode yang memberikan kesempatan yang banyak terhadap para siswa dalam berkelompok dengan kemampuan-kemampuan mereka yang beragam untuk memahami teks
\end{abstract}


recount. Tujuan dari penelitian ini yaitu untuk menyelidiki penggunaan pembelajaran kooperatif dan menemukan tanggapan para siswa mengenai penggunaan pembelajaran kooperatif untuk meningkatkan kemampuan pemahaman membaca bahasa Inggris mereka. Penelitian ini menggunakan metode campuran dengan menggunakan trianggulasi tepatnya rancangan satu kelompok pada saat sebelum pemberian perlakuan/pengajaran dan sesudah adanya perlakuan/pengajaran. Data kuantitatif diperoleh dengan menggunakan nilai siswa pada saat mereka test membaca teks recount sebelum dan sesudah adanya pemberian pengajaran. Sedangkan, data kualitatif diperoleh dari kelas observasi kelas dan wawancara. Penelitian ini diselenggarakan disalah satu sekolah berbasis Islam di wilayah Cianjur yang melibatkan 24 siswa kelas 8. Hasil penemuan menunjukkan bahwa tes hipotesis $t_{\text {hitung }} \geq t_{\text {table }} 14,29 \geq 1.714$. Oleh karena itu, hipotesis nol ditolak. Ini artinya, penggunaan pembelajaran kooperatif dapat meningkatkan kemampuan pemahaman membaca siswa. Penemuan lain menunjukkan bahwa tanggapan siswa positif. Mereka menanggapi bahwa pembelajaran kooperatif lebih menyenangkan. Tambahnya lagi, pembelajaran kooperatif membantu mereka memahami teks recount dan juga ini dapat diaplikasikan sebagai salah satu pengajaran membaca untuk diimplementasikan di Sekolah Menengah.

Kata Kunci: membaca, pemahaman membaca, pembelajaran kooperatif dan teks recount

\section{INTRODUCTION}

Reading in one of the skills in English, besides other skills namely listening, speaking and writing. The students who study at Elementary School, Junior High School, Senior High School and University level, particularly students who study in Indonesia learn it. It also plays an important role in learning process because it gives knowledge, information, and idea to be applied in speaking and writing. Through reading, students can learn ideas, concepts, enrich many 
vocabularies and attitudes. Moreover, they can know kinds of the text, meaning the words, main ideas, messages, and purposes of the text.

However, reading for students especially in Junior High School is one of the problems which they face at schools. They read all kinds of the text not to understand and comprehend what they have read. Richard and Renandya (2002, p. 227) states that reading for comprehension is the primary purpose for reading.

Besides that, lack of methods which the teachers use in the classroom could not support, help, and increase students' ability in English reading comprehension especially in Junior High School. So, it makes the students feel bored to read English text well.

\section{LITERATURE REVIEW}

Four fundamental theories that underpin of the present study. First, it discusses the theories about reading. It deals with the definition of reading, techniques in efficient reading, and recount text. Second, it elaborates the definition, process, and levels of reading comprehension. Third, it tells the principles and importances in teaching reading. Fourth, it explains the theory about cooperative learning. It deals with basic elements, types, class activities that use cooperative learning, teachers' role in cooperative learning, and advantages of cooperative learning. Fifth, it presents the previous study on improving students' ability in English reading comprehension through cooperative learning.

First theory about reading. Reading is the practice of using text to create meaning, reading is a constantly developing skill, reading integrates visual and non visual information, and reading is the act of linking one idea to another (Johnson, 2008, p. 3-4). Then, Reading means a result of interaction between the writer's mind and the reader's mind (Nuttal, 2000, p. 2). 
Second, it elaborates reading comprehension. Klingner et al., (2007, p. 8) define reading comprehension involves much more than readers' responses to text. Then, in reading comprehension needs 2 processes which different may be taken by the readers. First is the buttom-up approach, and second one is the top-down approach (Alderson and Bachman, 2002, p. 17).

Third, it tells the principles and importances in teaching reading. There are 10 principles which appropriate in teaching reading which are stated by Richards and Renandya (2002, p. 16). There are, lowering inhibitions, encouraging risktaking, building students' self confidence, helping students develop intrinsic motivation, promoting cooperative learning, encouraging students to use rightbrain processing, promoting ambiguity tolerance, helping students use their intuition, getting students to make their mistakes work for them, and getting students to set their own goals. Then, Hedge (2003) in Alyousef (2006, p. 67) states there are several importances in teaching reading including the ability to read a wide range of texts in English, building a knowledge of language which will facilitate reading ability, building schematic knowledge, the ability to adapt the reading style according to reading purpose (i.e. skimming, scanning), developing an awareness of the structure of written texts in English, and last one is taking a critical stance to the contents of the texts.

Fourth, it explains the theory about cooperative learning. Brown (2001, p. 47) states that cooperative learning is students work together in pairs and groups, they share information and come to each others' to get helps. They are "team" whose players must work together in order to achieve goals successfully. Meanwhile, there are types of cooperative learning which should be known before teaching learning in the classroom. As Jolliffe (2007, p. 43-44) states that cooperative learning utilises three types of cooperative learning groups. First is 
formal cooperative learning groups. Second is informal cooperative learning groups. Third is cooperative base groups. In the classroom, there are some activities in cooperative learning according Brown (2000, p. 15) including pair read, think-pair-share, numbered heads together, round table brain storming, and group discussion and quizzes. One of them which is chosen by the researcher in this study is think-pair-share. Then, Gillies (2008, p. 26-32) mentions there are three teachers' role in cooperative learning including formal, informal, and cooperative base groups. Cooperative learning also has three main categories of advantages according to Jolliffe (2007, p. 6). First, improvements in learning through greater productivity, higher process gain (that is, more higher-level reasoning, more frequent generation of new ideas and solutions) and others. Second, improvements in interpersonal relationships through promoting the development of caring and committed relationships, stablishing and maintaining friendships between peers, and others. Third, improvements in psychological health and social competence through higher self-esteem, improved self-worth, and others.

Fifth, it presents the previous study in supporting to this study which have been conducted by previous study on improving students' ability in English reading comprehension through cooperative learning. For instances the study is conducted by Wisnuwardana (2013), Hadyan (2013), and Abdurrahman et al., (2012).

\section{METHODOLOGY}

This study employed mix method design with a triangulation design. It means quantitative and qualitative method are used in this study. Research designs are types of inquiry within qualitative, quantitative, and mixed methods 
approaches that provide specific direction for procedures in a research design (Cresswell, 2014, p. 14). Regarding qualitative data, this study conducted classroom observation and interview. Meanwhile, in the quantitative data, this study employed one group pre-test and post-test design. Pre-test was given to the students before conducting treatments. Meanwhile post-test was given to the students after conducting the treatments. The research was conducted during 4 meetings.

This study was conducted at one of the kinds of Islamic school which is located in a regency around Cianjur namely MTs. Nurul Barokah Junior High School with several reasons inlcuding the facilities were complete and the students were difficult to comprehend English text.

The participants of this study consisted of 24 students including boys were 11 and girls were 13. Regarding the sample size, according to Hamied and Malik (2014, p. 85) affects accuracy of representation. Larger sample means less chance of error. Minimum is 30, upper limit is 1000. In this study, selection of participants used purposive sampling.

This study collected the data from several sources. According to Polit and Hungler (1999, p. 267) define that data information obtained during the course of an investigation or study. The researcher used some techniques for collecting the data. First is through classroom observation. Second is through test pre-test and post test of reading comprehension of recount text which consisted of 2 parts, namely multiple choice consisted of 10 questions and essay consisted of 5 questions. Third is through interview.

For classroom observation was conducted in every meetings. Meanwhile, For interview was conducted in the last meeting, after doing post-test. Both of them purpose to answer second research question. Then, for pre-test and post-test 
were conducted before and after giving treatments. Those tests were done in the first and last meeting of this study. Both of them purpose to answer first research question.

The data analyses were conducted to answer all the research questions. The data obtained from classroom observation, test (pre-test and post-test of reading comprehension), and interview are analyzed, categorized, and then interpreted into three themes based on the research questions.

\section{FINDING AND DISCUSSIONS}

This part, it is divided into two sessions based on the research questions as previous were discussed.

1. The Cooperative Learning Improves the Students' Ability in English Reading Comprehension

For acquiring the data for answering the first question, the researcher used test. The test consisted of pre-test and post-test. The pre-test was conducted in the first meeting was on 3 April 2017. Meanwhile, the post-test was conducted in the fourth meeting was on 8 April 2017. This study used one group pre-test and posttest design. It purposed to measure students' ability and knowledge for understanding text in English reading comprehension before and after giving treatments.

The researcher as a teacher in this study, so the researchers gave the paper of reading test of recount text to the students. After checking their job, the researcher found out the result of students's score in pre-test, the highest score (maximum) and the lowest score (minimum) should be possbile for the sample were, 70 for the highest score which student got, and 20 for the lowest score. For 
the total score from the whole students was 865 and average or mean from the total score was 36,04 .

Then, after the reasearcher gave treatments during 2 meetings. The students did post-test. This post-test purposed to know their understanding about reading comprehension of recount text by using cooperative learning.

The researcher found out that the students who got lowest score were 20 in pre-test became to improve their score were 70 in post-test. It meant that the minimum of the students' score was 70. In addition, the students who got highest score in pre-test was 70 became 90 score in post-test. It meant that the maximum of students' score in post-test was 90 . In other hand, the average of the students' total score was 74, 79. Meanwhile, the whole total score was 1.795 .

To examine the normality test, statistical result tested used by SPSS (the computer application for statistic test) version 16 . The normality test of data is gotten by using paired sample t-test (match t-test). The data from match t-test on SPSS version 16 could be compared with the manual calculation. If there was null hypothesis $\left(\mathrm{H}_{0}\right)$ was rejected. It is because if the $\mathrm{t}_{\text {count }}>\mathrm{t}_{\text {table }}$ in $d b=24$ with the significant level 0.05. It resulted $\mathrm{t}_{\text {table }}$ was 1.714 .

Hypothesis testing was $t_{\text {count }}>t_{\text {table }}$ was $14,29 \geq 1.714$. In addition, the result showed mean of pretest is 36.0416 and post-test 74.7916. Standard deviation of pre-test is 15.17859 and standard deviation of post test is 5.41318. 2-tailed is 0.00. So, the null hypothesis is rejected. Therefore, we assumed that cooperative learning could improve students' ability significantly in English reading comprehension of recount text at eight grade in MTs. Nurul Barokah Cianjur.

2. Students' Response in Using Cooperative Learning for Improving Students' Ability in English Reading Comprehension 
The responses of students in using cooperative learning of reading recount text was taken by the researcher in classroom observation and interview. In classroom observation was conducted during research. For the beginning of the learning, the students in the classroom began the learning by praying together loudly and slowly, and then full spirit. Then, they said greeting to the researcher by saying "assalaamu'alaikum warahmatullaahi wabarakaatuh." Then, the students prepared English lesson book, book, pencil and which related with the learning. After that, they said "present" when the researcher called each their name. However, several of them did not say "present" in English language, but they said by using Indonesian language and Sundanese language. (for the teaching learning activities in the classroom could be seen in appendix 2). In addition, there were several students who just raised their hands, not to say something. Then, when the researcher asked them about the material which they have learnt in the last meeting, they answered in orally by using variants of language.

The result of observation in the second and third meeting were quite different with the first meeting. It meant in the second and the third meeting, they were not clumsy, but they could learn more comfortable and more active in learning the material about recount text by using cooperative learning. When the researcher asked them to present what they had read in front of class, each group was ready to do it without caring their mistakes in pronunciation, correct or incorrect arrangements what they spoke and read. The researcher and other groups gave a question to each group who presented in front of the classroom. Each group who be asked could discuss and answer it each other by using English and Indonesian language. In the last session, several groups summarized orally about the material which they had learnt. In the last meeting, the students were ready to do test and students did it more serious and did not chat or ask each other. It was 
different condition with the first meeting (pre-test), in the last meeting they could answer the question as careful as possible. They used the technique which the researcher gave. They did not read it in long time, however they used the time wisely. It meant they tried to comprehend the text and use the time as wise as possible to answer the questions. Therefore, they could did the post-test on time.

From students' interview of using cooperative learning in improving students' ability in English reading comprehension. The researcher chose 12 students who became respondens by using purposive sampling. It was based on their score in pre-test and post-test. The questions for interview consisted 10 which have prepared.

From first question was about whether students liked English or not. The data showed that 9 liked English as an important lesson in this world. Meanwhile, 3 of them did not like yet about English. Students' reasons who liked English, “Karena kalau bisa bahasa Inggris hmmm.....saya bisa berkomunikasi dengan orang lain yang bisa bahasa Inggris." (Because if we can English hmmm...I can communicate with other people who can speak English). From second question was if learning English by using cooperative learning could improve their ability in English reading comprehension of recount text. There were 11 students responded that they liked to learn English with group. It meant by using cooperative learning as a method made the students were active in the classroom and made them were confident when reading the text in English. There are students' response, “ya jadi meningkat miss,”(yes, it can improve miss).

From third question was whether they had difficulties in reading English text. There were 9 of students who had difficulties in reading English text. Because they were seldom to read it in everyday. Meanwhile, 3 of students did not have difficulties, "banyak bu, karena jarang baca teks bahasa Inggris hhe" (there 
were more difficulties miss, because I seldom to read English text, hhe). From fourth question was whether the use cooperative learning motivate and made them interested in learning English. The students' responses were interested in cooperative learning and motivated them. "saya senang miss, jadi ingin terus berkelompok hheeee" (I felt happy miss, so I wanted to be with group hheeee).

From fifth question was whether the use of cooperative learning could improve their ability in learning English of recount text. There were 10 students who answered that their ability improved after using this method. "jadi meningkat miss" (so, it improved miss). From sixth question was strengths by using cooperative learning in understanding an English of recount text based on students' perception. There were students' response, “jadi bisa ngerti teks recount miss" (I became to understand about recount text, miss).

From seventh question was whether the researcher's explanation about recount text could be understood and could improve their ability of reading comprehension in recount text. The students' response were, "alhamdulillah ngerti dan lumayan meningkat, bu" (thank goodness, understood and quite to improve, miss). From Eighth question was whether cooperative learning could make them got easy to understand the recount text and could answer the questions which be provided. There were students' response, “ya bu, jadi lumayan gampang jawab soal", (yes miss, it was quite easy to answer the question),

From ninth question was whether students often used dictionary after learning with group if they got difficult to find out the meaning. There were students' response of it. "saya lebih suka menggunakan teknik yang ibu ajarkan, jadi gak terlalu melihat kamus" (I preferred to use technique which miss taught, so I did not too often look the dictionary). Last, from tenth question which the researcher asked to the students was whether cooperative learning could be used in 
other reading text. There were students' response, “ya, bu bagus tuh itu untuk teks yang lain" (yes miss, it was good for other text).

\section{CONCLUSION AND SUGGESTIONS}

Reading comprehension is reading which not only getting information, but also acquiring information as effective as possible. Reading comprehension in this study is about reading of recount text by using of cooperative learning to improve students' ability in English reading comprehension at eight grade students in MTs. Nurul Barokah Cianjur. The data were collected by using pre-test and post-test of reading test, classroom observation, and interview.

First, after analyzing from the test it could be looked the students' score in pre-test was lowest 20 became 70 in post-test, and the students who got 70 in pretest became 90 in post-test. So, the use of cooperative learning could improve students' ability significantly in English reading comprehension of recount text.

Second, after analyzing from the classroom observation, the researcher found that the students from the first meeting until the fourth meeting increased. In the first meeting, the students got boring in learning English. Meanwhile, in the second meeting until the last meeting, they were more spirit in learning English text especially of recount text.

Third, after analyzing the data from interview, it showed that students got difficulties in reading English text because they did not understand the English text, there were lack in vocabulary, grammar, then how to read English text, and less motivation to comprehend English text.

From the explanations above, there are several suggestions which the researcher offered as recommends from this study. Hopefully, these suggestions are useful especially for the teachers, for the students, for the next researchers, and 
for the readers. For the teachers will be better if this method can be used in teaching English for making students were more happy, active and also confident in learning English. Then, for the students should start to like this method to share, help, and work each other for achieving goal. Then, for the next researchers it can be used for giving contribution toward school in every level. Especially toward Junior High School. Last, for the readers can acquire the benefit from this study that cooperative learning can be used in teaching reading to improve students' ability in English reading comprehension, particularly of recount text

\section{REFERENCES}

Alderson, J. C. \& Bachman, L. F (2000). Assessing Reading. Cambridge: Cambridge University Press.

Brown, H. D. (2000). Principles of Language Learning and Teaching (fourth edition). New York: Pearson Education.

Brown, H. D. (2001). Teaching by Principle an Interactive Approach to Language Pedagogy. New York : Addison Wesley Longman, Inc.

Cresswell, J. W. (2014). Research Design: Qualitative, Quantitative and Mixed Methods Approaches. Sage: New Delhi.

Gillies, R. (2008). The Teacher's Role in Implementing Cooperative Learning in the Classroom. New York: Springer.

Hamied, F. A. \& Malik, R. S. (2014). Research Methods: A Guide for First Time Researchers. Bandung: UPI Press.

Johnson, A. P. (2008). Teaching Reading and Writing A: Guidebook for Tutoring and Remediating Students. Lanham, Maryland: Rowman \& Littlefield Education.

Jolliffe, W. (2007). Cooperative Learning in The Classroom Putting it into Practice. London: Paul Chapman Publishing.

Klingner, K. J., Vaughn, S., \& Boardman, A. (2007). Teaching Reading Comprehension to Students with Leraning Difficulties. New York: The Guilford Press.

Nuttal, C. (2000). Teaching Reading Skills in a Foreign Language. Oxford: Macmillan Heineman. 
Richards, J. C. \& Renandya, W. A. (2002). Methodology in Language Teaching: An Anthology of Current Practice. Cambridge: Cambridge University Press.

\section{JOURNAL}

Alyousef, H. S. (2006). Teaching Reading Comprehension to ESL/EFL Learners. $k @$ ta: Journal of Language and Learning, 5(1), pp. 63-73,

\section{WEBSITE}

Polit \& Hungler. (1999). Chapter 3 Research Methodology. Retrieved on February 26, 2017 from

http://www.google.co.id/search?site=\&oq=chapter+3+research\&aqs=mobil e-gus-lite.0:015\&q=chapter+3+research methodology 
THE IMPLEMENTATION OF COMMUNITY LANGUAGE LEARNING

(CLL) IN TEACHING SPEAKING

(A Qualitative Study at One of Universities in Cianjur)

By

Asep Saepuloh, S.S.,M.Pd

English Education Program

Teacher Training and Education Faculty

Suryakancana University

\begin{abstract}
Speaking is one of important aspects of language. Speaking plays an important role in transfering English speaking skill to students as well as the key to the success of teaching learning process of speaking. There are many methods or approaches used by lecturers in the classroom in teaching speaking in university, they however considered not so effective in stimulating students to be more active in speaking and to have more bravery and self confidence to use their own English although they may make more mistakes. Based on the depicted reality, the researcher feels chalenged to know how is the implementation of Community Language Learning (CLL) method, to investigate its strengths and weaknesses, as well as to find out students' difficulties in teaching s6peaking.

This research entitled The Implementation of Community Language Learning (CLL) in Teaching Speaking. This research is conducted on the second semester students of English Education Study Program who are taking Speaking For General Communication II on the second semester students at one of universities in Cianjur. This research aims to know how the implementation of
\end{abstract}


CLL and to investigate its strengths and weaknesses, as well as to find out students' difficulties in learning speaking through CLL.

This research uses qualitative method which employs several techniques in collecting the data. The data are obtained by conducting observation and interview.

\section{Keywords: Community Language Learning, teaching, and speaking}

\section{Introduction}

Nowadays the importance of English mastery in our daily lives is undeniable and inevitable due to the rapid growth of science and technology. Almost every single thing in our lives uses English as its introductory language, so mastering English in this era is really necessary since it is the answer to meet the need of globalization and the development of science and technology. As a whole, there are four basic skills in English should be mastered namely listening, reading, writting, and speaking. Yet, speaking is always regarded as the most crucial one since speaking is frequently used in our daily lives or interactions. An effective teaching method or approach is needed because it plays an important role in transfering English speaking skill to students as well as the key to the success of teaching learning process of speaking. There are many methods or approaches used by lecturers in the classroom in teaching speaking in university, yet considered not so effective in stimulating students to be more active in speaking and to have more bravery and self confidence to use their own English although they may make more mistakes. Based on the depicted reality, the researcher feels chalenged to know how is the implementation of Community Language Learning (CLL) method, to investigate its strengths and weaknesses, as well as to find out 
students' difficulties in teaching Speaking for General Communication II on the second semester students at one of universities in Cianjur.

This study investigates the following questions:

1. How is the implementation of CLL method in teaching speaking on the second semester students of English Education Program at one of universities in Cianjur.

2. What are the strengths and weaknesses of CLL method in teaching speaking on the second semester students of English Education Program at one of universities in Cianjur.

3. What are students'difficulties in implementing of CLL method in teaching speaking on the second semester students of English Education Program at one of universities in Cianjur.

Regarding to the research questions, the purposes of the study are as follow:

1. To know how the implementation of CLL method in teaching speaking on the second semester students of English Education Program at one of universities in Cianjur.

2. To investigate the strengths and weaknesses of CLL method in teaching speaking on the second semester students of English Education Program at one of universities in Cianjur.

3. To find out students'difficulties in implementing CLL method in teaching speaking on the second semester students of English Education Program at one of universities in Cianjur.

This study was conducted on the second semester students of English Education Program at one of universities in Cianjur. The concern of this study is the implementation, strengths, and weaknesses of CLL method in teaching 
speaking on the second semester students of English Education Program at one of universities in Cianjur.

This study is expected to give significance to the development of teaching and learning of speaking especially in a university where the research is conducted and generally in Indonesia. Hopefully, this study can be a solution on how to teach speaking effectively and also be a refferences for those who want to conduct research with similar topic. Practically, the research is expected to help lecturers of speaking course to provide some appropiate methods in teaching English speaking effectively.

\section{Theoretical Foundation}

Community Language Learning (also called Counseling Language Learning) was created by Charles A Curran, a Jesuit priest and professor of psychology, and Paul La Forge inspired by the humanistic psychology of Carl Rogers. It aims to remove the anxiety from learning by changing the relationship between the teacher and student. The Counseling-Learning educational model is applied to language learning, and in this form it became known as Community Language Learning seeks to encourage teachers to seetheir learners as whole persons, where their feelings, intellect, interpersonal relationships,protective reactions, and desire to learn are addressed and balanced.

CLL combines innovative learning tasks and activities. They include:

- Translation: Learners form a small circle. A learner whispers a message ormeaning he or she wants to express, the teacher translates or interprets it in thetarget language, and the learner repeats the teacher's translation.

- Group Work: Learners engage in various group tasks, such as smallgroupdiscussion of a topic, preparing a conversation, preparing a summary 
of a topicfor presentation to another group, preparing a story that will be presented to theteacher and the rest of the class.

- Recording: Learners record conversations in the target language.

- Transcription: Learners transcribe utterances and conversations they haverecorded for practice and analysis of linguistic forms.

- Analysis: Learners analyze and study transcriptions of target language sentencesin order to focus on particular lexical usage or on the application of particulargrammar rules.

- Reflection and observation: Learners reflect and report on their experience of theclass, as a class or in groups. This usually consists of expressions of feelings -sense of one another, reactions to silence, concern for something to say, etc.

- Listening: Learners listen to a monologue by the teacher involving elements theymight have elicited in class interactions.

- Free conversation: Learners engage in free conversation with the teacher or withother learners. This might include discussion of what they learned as well asfeelings they had about how they learned.

\section{Five Stages of CLL}

"The learner passes through five psychological stages as learning progresses, which Curran compares to the progressing from childhood to adulthood.

Birth: The learners know nothing of the target language, and are completely dependent on the teacher for everything they want to say.

Self: The learners start to get an idea of how the language works and to use it for themselves, but still seek the teacher's help. 
Separate Existence: They start to use the language without referring to the teacher.

Adolescence: The learners continue to express themselves independently, but beingaware of gaps in their knowledge, and start to turn back to the teacher.

Independence: The learners continue their learning independently. They no longerneed the teacher, and may start to act as counselors for less advanced students.

\section{Speaking}

According to Chaney, speaking is ithe process of building and sharing meaning through the use of verbal and non-verbal symbols, in a variety of contexts.

While another expert, Theodore Huebner said Language is essentially speech, and speech is basically communication by sounds. And according to him, speaking is a skill used by someone in daily life communication whether at school or outside. The skill is acquired by much repetition; it primarily a neuromuscular and not an intellectual process. It consists of competence in sending and receiving messages.

From the above definition, it can be inferred that speaking is expressing ideas, opinions, or feelings to others by using words or sounds of articulation in order to inform, to persuade, and to entertain that can be learnt by using some teaching and learning methodologies.

\section{Teaching Speaking}

Speaking is a crucial part of second language learning and teaching. Despite its importance, for many years, teaching speaking has been undervalued and English language teachers have continued to teach speaking just as a repetition 
of drills or memorization of dialogues. However, today's world requires that the goal of teaching speaking should improve students' communicative skills, because, only in that way, students can express themselves and learn how to follow the social and cultural rules appropriate in each communicative circumstance.

\section{a. What is Teaching Speaking?}

What is meant by teaching speaking is to teach English language learners to:

1. Produce the English speech sounds and sounds patterns.

2. Use words and sentence stress, intonation patterns and the rhythm of the second language. Theodore Huebner, Audio Visual Technique in Teaching Foreign Language, (New York: Cambridge University Press, 1960) p. 5

3. Select appropriate words and sentences according to the proper socialsetting, audience, situation and subject matter.

4. Organize their thoughts in a meaningful and logical sequence.

5. Use language as a means of expressing values and judgments.

6. Use the language quickly and confidently with few unnatural pauses, which is called fluency. (Nunan 2003)

\section{b. How to Teach Speaking?}

Now many linguistics and English as second language (ESL) teachers agree on that students learn to speak in the second language by "interacting". Communicative language teaching and collaborative learning serve best for this aim. Communicative language teaching is based on real life situations that require communication. By using this method in ESL classes, students will have the opportunity of communicating with each other in the target language. In brief, ESL teachers should create a classroom environment where students have real-life communications, authentic activities, and meaningful tasks that promote oral language. This can occur when students collaborate in groups to achieve a goal or 
to complete a task. (Ayu Diyah Harni Susanti. 2017. Using Role Play In Teaching Speaking)

\section{Research Methodology}

This research employed a qualitative research method that attempts to describe the implementation of Community Language Learning (CLL) method in teaching speaking on the second semester students of English Education Program at one of universities in Cianjur. This research took place on the second semester students of English Education Program at one of universities in Cianjur. The subjects of the research were 29 students of the second semester of English Education Program at one of universities in Cianjur. There were 6 male students and 23 female students. This class was chosen since they were taking Speaking for General Communication II course on the second semester.

In this research, the researcher uses two instruments for the data collection namely observation and interview.

\section{Observation}

According to Arikunto, observation is a technique of data collection which is done by conducting thorough research, as well as systematically recording. In observation activities, the researcher is not involved in teaching learning process done by the lecturer and students. The researcher only observes and monitors the teaching and learning process of speaking, and makes recording as well.

\section{Interview}

In order to dig deep information about the data, the researcher also performs an interview. According to Esterberg, interview is a meeting of two 
persons to exchange information and idea through questions and responses, resulting in communication and joint construction of meaning about a particular topic.

\section{Data Analysis}

In this research, the researcher describes, explains, understands, and interprets the objects or event to which researcher's data refers. Therefore, data analysis in every research was absolutely important to elicit the real and structural information based on research question. Data analysis is a process of resolving data into its constituent components, to reveal its characteristics elements and structure. In more detail step, the researcher also conducted some steps in analyzing the data obtained.

Relating to the interview data, the researcher listened to the recording of interview, transcribed into transcription, read the transcription, drew the points, and put it into general trend or theme. Almost the same interview data, in observation data, the researcher classified the data collected into general trend and theme based on the research question. Mathew and Huberman stated that there are several steps in this process, they are collecting data, data reduction, data display, drawing conclusion and verification. Here is the further explanation about the steps.

\section{Findings And Discussions}

This chapter discusses the data obtained from classroom observations and interviews. The data are used to answer all of the research questions. The first research question investigates the implementation of Community Language Learning (CLL) in teaching speaking on the second semester students, the second is the strengths and weaknesses of CLL in teaching speaking on the second 
semester students, and then the third explores students' difficulties in learning speaking through CLL method. The findings of each research question are discussed in depth in the following sections.

\section{The Implementation of Community Language Learning in Teaching Speaking.}

In this research, the classroom observations were conducted in a single class, particularly on the second semester students of English Education Program at one of universities in Cianjur, and it was held three times exactly on Wednesday, 8, 15, 22 February 2017 based on schedule of the course.

Based on the observation results, the observer found that the students really enjoyed the learning process. It was reflected from their attitude and response during the course. The findings can be seen from observation results from the first meeting until the last meeting.

Data from interviews supported the data gained from the classroom observations. The interviews were held after the classroom observation had finished and involved three students. The researcher orally asked questions for three students. The interview explored all research questions well.

In this case, the interviews were conducted at the end of the lesson in the last meeting on Wednesday, February 22nd, 2017 by using tape recorder. The interview lasted 3-5 minutes for each student. The interviewer selected the interviewee based on their high, middle, and low participation and motivation during the course.

The interviews concerning to the first research question related to the Implementation of Community Language Learning on the second semester students of English Education Program at one of universities in Cianjur. Based on 
the data from interviews, it was found that the students prefered CLL to any other methods. Most students enjoyed the learning process because CLL was fun and chalenging for them. It can be seen from their attitude and response during the course. The students were so enthusiastic when learning speaking.

Referring to the description above, it was inferred that the students got the steps of Community Language Learning (CLL) implemented completely but it still needed some improvements. Although the teaching-learning process of speaking implemented the steps of CLL completely, but a few of students were not so enthusiastic in the learning process. Students' seriousness could be seen from their participation in the learning process.

\section{The Strengths and Weaknesses of Community Language Learning in Teaching Speaking}

Based on the result of the classroom observations and interviews, there were four strengths and three weaknesses in implementing Community Language Learning in teaching speaking. First CLL method can encourage students to be more independent in doing their activities in the classroom, second this method also creates a pleasant and conducive atmosphere that is suitable for speaking learning environment, third this method increases students'self-confidence especially for the slow learners, fourth this method allows students to have the freedom and inisiative as much as they want because they are actively involved in designing and formulating the learning process plan along with their lecturer.

Furthermore, there are three weaknesses that the researcher found in Community Language Learning. First CLL method tends to provide students with the low difficulty level learning, second the success of this method depends largely on the feedbacks of the lecturer as the counselor, third the evaluation test to see the 
progress that students have may be more complicated to be done than in ordinary classroom that does not use this method.

\section{Students' Difficulties in Learning Speaking through Community Language Learning Method}

Based on the result of classroom observations and interviews, there are some students' difficulties in learning speaking through Community Language Learning, such as it is difficult for students to develop the topic for speaking activity, to express their opinions and ideas due to the lack of vocabulary and understanding of sentence structure, to respond the lecturer instruction or questions spontaneously because of the limited vocabularies, sentence structure and the lack of speaking practice, to make their ideas accomodated, to choose learning materials and activities in each meeting, and to understand the material delivered by lecturer.

\section{Conclusions And Suggestions}

\section{Conclusions}

This research reports the result of CLL implementation in teaching speaking on the second semester students of English Education Program at one of universities in Cianjur. The aims of the research are to know how the implementation of CLL in teaching speaking, to investigate the strengths and weaknesses of CLL, and to find out students' difficulties in learning speaking through CLL method. Based on the data analysis and discussions in the previous chapter, the researcher would like to draw conclusions as follows.

1. First, according to the data from the previous chapter shows that CLL method creates pleasant and conducive learning situation for students as 
well as creates good athmosphere in the classroom. The evidence can be seen from the classroom observation and interview results from their attitude and response to the lecturer in the classroom.

2. Second, refer to the data from the previous chapter shows strengths and weaknesses of CLL in teaching speaking. It can be shown from classroom observation and interview results that there are several strengths such as encouraging students to be more independent in doing their activities in the classroom, creating a pleasant and conducive atmosphere that is suitable for speaking learning environment, increasing students'self-confidence especially for the slow learners, and allowing students to have the freedom and inisiative as much as they want because they are actively involved in designing and formulating the learning process plan along with their lecturer. Furthermore, the result of classroom observations and interviews reveal that there are several weaknesses such as providing students with the low difficulty level learning, depending largely on the feedbacks of the counselor, and complicated evaluation test to see the progress of the students.

3. Third, based on the data from the previous chapter shows that students found the following difficulties such as developing the topic for speaking activity, expressing their opinions and ideas, responding the lecturer instruction or questions spontaneously, choosing learning materials and activities in each meeting, and understanding the material delivered by lecturer.

\section{Suggestions}

The present study offers several practical suggestions. The suggestions can be drawn into two parts. 
1. First, this research suggests several guidelines for lecturers who want to implement Community Language Learning method in their teaching, especially in teaching speaking. The research suggests that lecturers who use CLL method undertand its stages, procedures, and techniques, so the lecturer can implement it well in the classroom and also it can make the speaking learning process successful through alleviating anxiety, threat, and language problems that the students encounter in the learning procces.

2. Second, this research suggests that the researchers who have the same interests on CLL, to implement this method in teaching any other skills, disciplines, courses, and in different levels as well. 


\section{REFERENCES}

Arikunto, Suharsimi. 2006. Prosedur Penelitian Suatu Pendekatan Praktik, Jakarta: PT Rineka Cipta.

Banister, Peter. 2011. Qualitative Methods in Psychology. Open University Press.

Curran, Charles A. 1976. Counseling-Learning in Second Languages. Apple River Press.

Chaney, A. L and F L. Burk. 1998. Teaching Oral Communication. In Grades K:2005. Boston: Allyn \& Bacon.

Esterberg, Kristin G. 2002. Qualitative Methods Ins Social Research. Mc Graw Hill, New York.

Miles, Matthew B. and A. Michael Huberman. 2004. Qualitative Data Analysis (terjemahan). Jakarta: UI Press.

Nunan, David. 2003. Practical English Language Teaching. New York: Mc Grow Hill Contemporary

Nagaraj P. 2009. Application of Community Language Learning for Effective Teaching. The Modern Journal of Applied Linguistics.

Theodore, Huebner. 1960. Audio Visual Technique in Teaching Foreign Language. New York: Cambridge University Press. 


\section{THE USE OF NUMBERED HEADS TOGETHER TECHNIQUE}

IN TEACHING SIMPLE PAST TENSE

(A Quasi-Experimental Study at the Tenth Grade Students of SMA Negeri 1 Cibeber)

\section{A RESUME}

Submitted to English Education Study Program of Suryakancana University in Partial Fulfillment of the Requirements for the Sarjana Pendidikan Degree

by

Muhamad Ilham Hikmawandiny $\mathbf{8 8 2 0 3 1 3 0 6 7}$

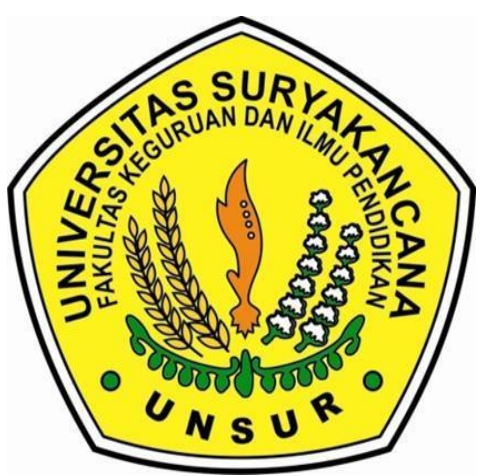

ENGLISH EDUCATION STUDY PROGRAM FACULTY OF EDUCATION AND TEACHER TRAINING SURYAKANCANA UNIVERSITY

CIANJUR

2017 


\begin{abstract}
The research was aimed at discovering whether Numbered Heads Together technique is effective to improve students' ability in simple past tense and finding out the student's responses toward this technique. The quasi-experimental design was utilized in order to collect the data. This quantitative research involved two classes of tenth grade at one senior high school in Cianjur in which one class was assigned as the experimental class and the other one was assigned as the control class. The instruments used were pre-test, post-test, and questionnaire attitudes towards the Numbered Heads Together technique. The pre-test was conducted in which the pre-test mean scores were the bases in identifying the initial learning framework of the participants. After conducting the selected lessons that employed the Numbered Heads Together technique in experimental class and employed Grammar Translation Method in control class, the students of both classes were given a post-test. The gain score of the two classes were compared by using Independent t-test. Results showed that the significance value was less than the significance level which was $0.032<0.05$. It means that the Numbered Heads Together technique is effective to improve the students' ability in simple past tense. Based on the questionnaire analysis, the findings showed that most of the students agreed that employing the Numbered Heads Together technique helps them to be more confident in term of participating because of group encouragement and benefits them to understand the hard concept of the learning material. Thus it can be concluded that the students' responses toward the Numbered Heads Together technique were positive.
\end{abstract}

Keywords: Numbered Heads Together, cooperative learning, simple past tense 


\begin{abstract}
ABSTRAK
Penelitian ini bertujuan untuk mengetahui apakah teknik Numbered Heads Together efektif untuk meningkatkan kemampuan siswa tentang simple past tense dan mengetahui tanggapan siswa terhadap penggunaan teknik tersebut. Dalam penelitian ini, desain kuasi-eksperimental digunakan untuk mengumpulkan data. Penelitian kuantitatif ini melibatkan dua kelas tingkat sepuluh di suatu sekolah menengah atas di Cianjur, dimana satu kelas sebagai kelas eksperimen dan satu kelas lainnya sebagai kelas kontrol. Instrument yang digunakan adalah pre-test, post-test, dan kuesioner sikap terhadap teknik Numbered Heads Together. Pre-test dilakukan untuk mengetahui nilai rata-rata siswa di awal penelitian. Setelah dilakukan pembelajaran simple past tense dengan teknik Numbered Heads Together untuk kelas eksperimen dan teknik Grammar Translation Method untuk kelas kontrol, siswa pada kedua kelas diberikan post-test. Skor perolehan kedua kelas kemudian dibandingkan dengan uji $\mathrm{t}$ independen. Hasil penelitian menunjukkan bahwa nilai signifikansi hasil uji kurang dari tingkat signifikansi yaitu $0.032<0.05$. Artinya teknik Numbered Heads Together ini efektif untuk meningkatkan kemampuan siswa dalam simple past tense. Berdasarkan hasil kuesioner, ditemukan bahwa sebagian besar siswa setuju dengan menggunakan teknik Numbered Heads Together dapat membantu mereka untuk lebih percaya diri untuk berpartisipasi dalam keolmpok dan memberi manfaat bagi mereka untuk memahami konsep materi pembelajaran yang sulit. Dengan demikian dapat disimpulkan bahwa tanggapan siswa terhadap teknik Numbered Heads Together bersifat positif.
\end{abstract}

Kata Kunci: Numbered Heads Together, pembelajaran kooperatif, simple past tense 


\section{Introduction}

English is a foreign language in Indonesia and it is studied in formal education from elementary school to university. As one of the subjects that is examined in the national exam, the English is the main subject and an obligatory to be studied by the students. Based on the Education and Culture Minister Regulation (Permendikbud) no. 21 year 2016, one the English language teaching scopes for senior high school in Curriculum 2013 is comprehend the supporting competencies. The supporting competencies included linguistic competence such as the ability to use grammar, vocabulary, pronunciation, and writing arrangement.

Grammar is very necessary to learn because with grammar the students can communicate clearly especially in writing and speaking. As Harmer (2010:32) in Syukron et al (2016: 2) states that grammar can thus be partly as knowledge of word can go where and what form these word should take. Studying grammar means knowing how different grammar element can be strung together to make chain of words. But in fact, when the students learn English at school, grammar is one of the subjects that avoided by the students. It is reasonable, because grammar covers many tenses with different functions and formulas. Beside that there is the change of some verbs based on the tenses that we use, including in simple past tense.

When the writer did the observation in tenth grade of SMA Negeri 1 Cibeber, the writer found that the students feel confused to understand and hard to memorize the lessons especially in learning simple past tense. It could cause by some factors, one of them is the teaching technique. Hence, the teacher must apply the easiest way to teach English especially teaching simple past tense, to make the students not only get the material but also enjoy the method.

Cooperative learning as one of teaching methods is alternative way in teaching learning process. According to Haydon et al. (2010: 224) states that cooperative learning strategies are effective because they increase pupil response opportunities, provide more immediate and frequent feedback, increase the 
number of complete learning trials, and offer students the opportunities to serve as teachers and learners. Cooperative learning has many kinds of techniques, one of the techniques is Numbered Heads Together.

According to Kagan in Maheady et al (2006:27), NHT involves dividing the class into small (4 members), heterogeneous learning teams within which pupils number themselves (1 to 4). Pupils "put their heads together" in response to each teacher question, come up with the best answers they can, and make sure that everyone on the team knows the answer. The activity in NHT technique is expected to train the students to socialize and help each other. NHT can grow the responsibility among students because each student must give a contribution to their group for the best result in doing any assignment. According to Huda (2014: 138), NHT technique can be apply in all of the subjects and class level.

Based on the explanation above, the writer would like to conduct an experimental research at tenth grade students of SMA Negeri 1 Cibeber that concern to the use of Numbered Heads Together technique in teaching simple past tense.

Based on the background the writer conducts the study aim is to answer 2 research questions:

1. How the Numbered Heads Together technique effective to improve students' ability in simple past tense?

2. What are students' responses toward Numbered Heads Together technique applied in the classroom? 


\section{Literature Reviews}

\section{A. Simple Past Tense}

According to Azar (1992: 18) says that the simple past is used to talk about activities or situation that began and ended in the past. While according to Macella Frank (1997: 49) as cited in Hizbullah (2010: 7) states that the simple past tense represents definite time, it refers to event that was completed before the statement is made.

The simple past tense formed with subject + auxiliary verb did + main verb. The simple past tense is formed with the past form of the verbs which may be either regular, i.e. by adding -ed to the infinitive form (incidentally, most verb are regular) or irregular which must be learned and memorized in each case (Mahmud, 2003:88).

According to Azar (1992: 19), here are the forms of the simple past tense.

Table 1. Forms of Simple Past

\begin{tabular}{|c|c|c|c|}
\hline Statement & & $\{$ I-You-She-He-It-We-They $\}$ & $\begin{array}{l}\text { worked yesterday. } \\
\text { ate breakfast. }\end{array}$ \\
\hline Negative* & & $\{$ I-You-She-He-It-We-They $\}$ & $\begin{array}{l}\text { did not (didn't) work yesterday. } \\
\text { did not (didn't) eat breakfast }\end{array}$ \\
\hline Questions* & Did & $\{$ I-You-She-He-It-We-They $\}$ & $\begin{array}{l}\text { work yesterday? } \\
\text { eat breakfast? }\end{array}$ \\
\hline Short Answer & $\begin{array}{l}\text { Yes, } \\
\text { No, }\end{array}$ & $\{$ I-You-She-He-It-We-They $\}$ & $\begin{array}{l}\text { did. } \\
\text { didn't }\end{array}$ \\
\hline
\end{tabular}

*Note: Did is not used with was and were.

According to Quirk and Greenbaum (1973: 28), lexical verbs in English considered into two heads: regular (such as call) and irregular (such as drink). Regular verbs always end with a $-d$ in the simple past, but we do not always pronounce the $-d$ ending in the same way. In another statement Quirk and Greenbaum (1973: 28) says that we usually add -ed to the base form of the verb: $I$ play - I played, I open - opened. Irregular verbs differ from the regular verb. It is typically, but not necessarily, has variation in their base vowel: write - wrote written.

Based on the explanation above, it can be seen that the regular verb and irregular verb have different rules in their four principal parts. For the regular 
verbs, the past tense and past participles forms are spelt by adding $-d$ or $-e d$ to base form. While, for irregular verbs the past and past participles must be memorized because irregular verbs have unpredictable past tense and past participles forms.

\section{B. Grammar Translation Method}

The purpose of the Grammar Translation Method was to help students read and understand foreign language literature (Larsen-Freeman, 2000: 11). In order to communicate accurately, meaningfully, and appropriately skills and practice students need are provided using the Grammar Translation Method (Fish, 2003 in Mart, 2013: 103).

According to Prator and Celce-Murcia (1991) as cited in Esmaeil Heydari Asl et al (2015: 19), the characteristics of Grammar Translation Method are : (1) Classes are taught in the mother tongue, with little active use of the target language; (2) Much vocabulary is taught in the form of lists of isolated words; (3) Long elaborate explanations of the intricacies of grammar are given; (4) Grammar provides the rules for putting words together, and instruction often focuses on the form and inflection of words; (5) Reading of difficult classical texts is begun early; (6) Little attention is paid to the content of texts, which are treated as exercises in grammatical analysis; (7) Often the only drills are exercises in translating disconnected sentences from the target language into the mother tongue; and (8) Little or no attention is given to pronunciation.

Meanwhile the techniques of Grammar Translation Method as states by Larsen-Freeman (2000: 19) are: translation of literary passage; reading comprehension questions; antonyms, anonyms; fill in the gaps; memorization; and use words in sentence.

\section{Cooperative Learning}

Cooperative learning is now utilized in schools and universities throughout most of the world in every subject area and from preschool through graduate school and adult training programs (Johnson \& Johnson, 2009: 365). Slavin 
(1996) as cited in Tsay and Brady (2010: 79) states that cooperative learning is teaching method in which students work together in small groups to help one another learn academic content.

There are some kinds of cooperative learning techniques, Olsen and Kagan in Kessler (1992: 88) describe the example of cooperative learning activities are Three-Steps-Interview, Roundtable, Think-Pair-Share, Jigsaw, and Numbered Heads Together. In this research will concern to the use of Numbered Heads Together technique.

\section{Numbered Heads Together}

Numbered Heads Together is one of components in cooperative learning that is use as media to apply this method when discussion process (Kagan, 1992 in Syawalia, 2013: 13). This technique emphasizes on the special structure designed to influence the pattern of students' social interaction in the class, and its goal is to reach the objective of materials and to improve the academic mastery.

According to Cruikshank (2006: 238) in Rahmi \& Syahputra (2016: 42). states that there are four characteristics of cooperative learning method including Numbered Heads Together technique are: (1) How is the group team made up; (2) Choosing the task; (3) Groups' rule of behavior; (4) Motivation and reward system.

In conducting the Numbered Heads Together technique in the class, the teacher should use the following four steps structure (Cayabyab and Jacobs, 1999: $30)$.

\section{Numbering}

The teacher divides students into a group, every group consist about three until six students. Then, each member of them is given number from one to six.

\section{Asking the Question}

Teacher asks a question to students. The teacher distributes the text/material that will be discussed to the students. Before start the 
lesson the teacher asks some guiding questions to the students. Teacher introduces the text after the students guess the topic and the title of the text first. Teacher asks the students a question or sets a problem to solve. It must be stressed that everyone in the group must be able to participate and answer the question.

\section{Heads Together}

Students put their heads together, answer the question, and make sure each team number understands and can explain the answer. In here, the students work together in order to solve the problem and also ensure that everyone in the group can answer the question.

\section{Answering}

Teacher calls a number at random. The students with that number raise their hands to be called upon. The teacher now asks for answer by calling a number. The students with the number called then take to answer. If there are not enough students ready to respond the teacher may judge that a little more time is needed. 


\section{Method}

In this research, the writer uses quantitative method in the design quasiexperimental research. Quantitative research focuses on testing objective theories by examining the relationship among variables (Malik and Hamied, 2014: 36). Meanwhile, according to McMillan and Schumacher in Ridwan (2014: 19) states that quasi-experimental research is a good design of the research because although it is not true experiment, it provides reasonable controlled over most sources of individuality and it is usually stronger than the pre-experimental design. Schematically, the quasi-experimental design can be drawn as follows:

Table 2. The Schematic of the Quasi-experimental Design

\begin{tabular}{|c|c|c|c|}
\hline Group & Pre-test & Treatment & Post-test \\
\hline Experimental & Xe 1 & $\mathrm{~T}$ & Xe 2 \\
\hline Control & Xc 1 & $\mathrm{O}$ & Xc 2 \\
\hline
\end{tabular}

The writer conducted experiment in two different classes with two different methods. The first class as an experimental class taught using Numbered Heads Together technique $(\mathrm{T})$. The second class as a control class taught using Grammar Translation Method (O). After pre-test $(\mathrm{X})$ and post-test $(\mathrm{X})$ conducted, the writer analyzed the data using t-test to compare and determine the final calculation of the research.

\section{A. Population and Sample}

Population is any group of people that have one or more characteristics in common that become the researcher's interest, while samples are a small part of a population selected for observation and analysis (Best \& Khan, 1995: 13). The population of this research is the tenth grade of SMA Negeri 1 Cibeber. Because there are many students in tenth grade at this school, the writer cannot choose the whole students as a sample. In all research models we cannot study the whole population of our interest, it is essential to select a sub-set (sample) from the target population on which we want to generalize our findings (Malik \& Hamid, 2014: $83)$. The sample was taken purposively where there are 21 students of class 
X IPS 2 as an experimental class which is using Numbered Head Together Technique. While, there are 18 students of X IPS 4 as a control class which is using Grammar Translation Method in teaching simple past tense. So, totally the researcher took 39 students as the sample.

\section{B. Instruments}

The instruments that used in this research are test, treatment, and questionnaire:

1) Test

There are three tests in this research, the first is tryout test. Tryout test was conducted to examine the validity, reliability, and difficulty of the items before administer in experimental class and control class. From 25 items that tested, only 20 items which are valid and used at the experiment. The second is pre-test, was conducted in both classes in order to get the sample that has a comparative relatively the same which is consist of 20 multiple choice items. The third is post-test, it conducted in the last after give the treatment to the students. It has a purpose to determine the growth of learning outcome with the two methods used in the research. The questions in post-test were similar like in the pre-test, consist of 20 items of multiple choices questions.

2) Treatment

The treatment was given to experimental class and control class after both classes doing pre-test. The experimental class taught by using Numbered Heads Together technique, while control class taught by using Grammar Translation Method. Even though the methods that applied in both of experimental and control class were different, the learning materials and context were approximately similar.

3) Questionnaire

In the last of meeting the writer give a questionnaire to experimental class to know the students' responses about the use of Numbered Heads Together technique in teaching simple past tense, 
whether positive or negative. The questionnaire was constructed based on Likert scale and consisted of 20 questions. The students responded to the following questions by placing a check mark in the area of the rating scale that corresponds with their opinion.

\section{Data Analysis}

The test consists of 20 questions when the right answer get score 4, in which the maximum score is 100 , and the wrong score get score 0 . The data from pretest, post-test were analyzed by using independent t-test through software SPSS 20 for Windows with certainty the data must normal and homogenous. The t-test was conducted to determine whether or not there is a significant difference between the experimental and control classes' means on dependent variable (Coolidge, 2000: 141). In this research, the significance level was set up at 0.05.

To analyze the data from questionnaire, the writer use the percentile formula through software Ms. Office Excel 2010. According to Hatch and Farhady (1982: 46), the percentile formula is formulated as follows:

$\mathrm{P}=$ Percentile

$\mathrm{F}=$ Frequency of students' answer

$\mathrm{N}=$ Respondent 


\section{Result and Findings}

\section{The Effectiveness of Numbered Heads Together Technique in Teaching Simple Past Tense}

After conducting the pre-test and post-test at the both classes, the statistical description of the finding will be describe as follows:

Table 3. Statistical Description of the Findings

\begin{tabular}{|l|l|c|c|c|c|c|}
\hline \multicolumn{2}{|c|}{} & N & Minimum & Maximum & Mean & $\begin{array}{c}\text { Std. } \\
\text { Deviation }\end{array}$ \\
\hline \multirow{2}{*}{ Pre-test } & Experimental & 21 & 25 & 70 & 47.14 & 13.836 \\
\cline { 2 - 7 } & Control & 18 & 25 & 70 & 46.11 & 14.907 \\
\hline \multirow{2}{*}{\begin{tabular}{l} 
Post-test \\
\cline { 2 - 7 }
\end{tabular}} & Experimental & 21 & 45 & 90 & 71.90 & 11.670 \\
\cline { 2 - 7 } $\begin{array}{l}\text { Index } \\
\text { Gain }\end{array}$ & Control & 18 & 45 & 85 & 64.44 & 10.556 \\
\cline { 2 - 7 } & Cxperimental & 21 & 10 & 45 & 24.76 & 8.728 \\
\hline
\end{tabular}

At the beginning, the data finding was analyzed its normality and homogeneity. The result shows that the data of pre-test, post-test and index gain are normal and homogenous so it can be continued to analyzed by using independent t-test. Here are the descriptions of independent $t$-test that conducted at the pre-test, post-test, and index gain in the following table.

Table 4. Independent t-test

\begin{tabular}{|l|c|}
\hline \multicolumn{1}{|c|}{ Data } & Sig. (2-tailed) \\
\hline Pre-test & 0.824 \\
\hline Post-test & 0.045 \\
\hline Index Gain & 0.032 \\
\hline
\end{tabular}

Based on the Table 4, the t-test analysis at pre-test shows that, there is no significant difference between the experimental and control class for their pre-test scores because the significance value is higher than significance level or $0.824>$ 0.05. It means, the score of experimental class students and control class students is relatively same at the beginning.

And then, t-test was conducted to see the difference in the learning outcomes between experimental class students and control class students. Based 
on the Table 2, the t-test shows that the significance value is 0.045 or less than 0.05 , so it means that the learning outcomes of experimental class is better or higher than control class students.

To strengthen the results of post-test analysis in this study, the index gain of the test was analyzed. The aim of this analysis is to know whether the improvement of the students' ability about simple past tense in both classes is difference or not. The data of index gain is normal and homogenous so, the last test that conducted to the index gain is independents sample t-test, in order to know whether or not is there any significant difference in the improvement of students' achievement between experimental class and control class. Based on the Table 2, the t test result shows that the significance value is less than 0.05 or 0.32 $<0.05$, it means that the improvement of students' ability about simple past tense in experimental class is higher than students in control class.

Based on the discussion above, the used of Numbered Heads together in experimental class is better than control class that used Grammar Translation Method. The experimental students get higher post-test and index gain score than control class. So, the conclusion is the Numbered Heads Together technique is effective in teaching simple past tense to improve the students' comprehension.

\section{The Students' Responses toward The Numbered Heads Together Technique in Teaching Simple Past Tense}

Beside the improvement of students' comprehension about simple past tense that can be seen from the index gain data, the students' response to the use of Numbered Heads Together technique in teaching simple past tense can be seen from the result of questionnaire analysis. Based on the questionnaire, shows that commonly students (89\% from 21 students) in experimental class show positive response to the English subject. It means that most of the students are interested and happy to learn English as one of the subject in the school. Furthermore, the questionnaire data shows that generally students (87\% from 21 students) in experimental class give a positive response to the implementation of Numbered 
Heads Together technique in teaching simple past tense. So, the conclusion is generally students ( $88 \%$ from 21 students) give positive response to the use of Numbered Heads Together technique in teaching simple past tense. 


\section{Conclusion}

Based on the data analysis and discussion, the conclusion of the study showed that the experimental class students, which employed the Numbered Heads Together technique, achieved better score than the control class students, which employed the Grammar Translation Method. The analysis in index gain of the both classes showed that the significance value is less than 0.05 so, $\mathrm{H}_{0}$ is rejected and $\mathrm{H}_{1}$ is accepted. It means that Numbered Heads Together technique is effective to improve students' ability in simple past tense.

Most of the students agreed that employing the Numbered Heads Together technique helps them to be more confident in term of participating because of group encouragement and benefits them to understand the hard concept of the learning material. When they were in group, they could solve the difficulties in learning English because they could share their knowledge. In addition, they believe that the Numbered Heads Together technique stimulates them to think critically when they want to solve the problems during active activities. 


\section{Bibliography}

Asl, Esmaeil H. et al (2015). Comparative Study of Grammar Translation Method (GTM) and Communicative Language Teaching (CLT) in Language Teaching Methodology. Human Journals. 1(3), pp. 16-26.

Azar, B. S. (1992) Fundamentals of English Grammar. New Jersey: Prentice Hall.

Best, J.W., \& Khan, J.V. (1995). Research in Education (7th ed.). New Delhi: Houghton Mifflin Company.

Cayabyab, E. C., \& Jacobs, G. M. (1999). Making small groups work via cooperativelearning. The ACELT Journal, 3(2), 27-31.

Coolidge, F.I. (2000). Statistics: A gentle introduction. London, Thousand Oaks, New Delhi: SAGE Publications.

Hatch, E., \& Farhady, H. (1982). Research design and statistics for applied linguistics. Rowley: Newbury House Publishers. Inc.

Haydon, T., Maheady, L., \& Hunter, W. (2010). Effects of numbered heads together on the daily quiz scores and on-task behavior of students with disabilities. Journal of Behavioral Education, 19(3), 222-238. doi:10.1007/s10864-010-9108-3.

Hizbullah (2010). Teaching simple Past Tense by Using Cooperative Learning. Jakarta: Syarif Hidayatullah State Islamic University.

Johnson, D. W., \& Johnson, R. T. (2009). An educational psychology success story: Social interdependence theory and cooperative learning. Educational researcher, 38(5), 365-379.

Kemendikbud. (2016). Permendikbud No. 21 tentang Standar Isi Pendidikan Dasar dan Menengah. Jakarta: Kementerian Pendidikan dan Kebudayaan.

Kessler, Carolyn. (1992). Cooperative Language Learning. New Jersey: PrenticeHall.

Lersen-Freeman, D. (2000). Technique and Principles in Language Teaching. New York: Oxford University Press.

Maheady, L., Michielli-Pendl, J., Harper, G. F., \& Mallette, B. (2006). The effects of numbered heads together with and without an incentive package on the science test performance of a diverse group of sixth graders. Journal of Behavioral Education, 15(1), 25-39. doi:10.1007/s10864-005-9002-6.

Mahmud, N. (2003). English fo Muslim University Students (3rd ed). Jakarta: Pusat Bahasa dan Budaya Universitas Islam Negeri Jakarta. 
Malik, R. S. \& Hamied, F. A. (2014). Research Methods: A Guide For First Time Researchers. Bandung: UPI Press.

Mart, C. T. (2013). The Grammar-Translation Method and the Use of Translation to Facilitate Learning in ESL Classes. Journal of Advances in English Language Teaching, 1(4), pp-103.

Quirk, R. \& Greenbaum, S. (1985) A University Grammar of English. Essex: Longman Group Limited.

Rahmi, R., \& Syahputra, M. (2016). The Use of Number Heads Together (NHT) in Teaching Speaking for Junior High School. Getsempena English Education Journal, 2(1).

Ridwan, S. F. (2014). The effectiveness of Jigsaw Technique in Teaching Simple Past Tense. Jakarta: Syarif Hidayatullah State Islamic University.

Syawalia, T. S. (2013). Cooperative Learning in Subject English Reading Skill: A Quasi Experimental Study on the First Grade in Private Senior High School (Doctoral dissertation, Universitas Pendidikan Indonesia).

Syukron, M. B., Suryanti, Y., \& Sofyan, D. (2016). An Anaysis on Students'difficulties in Understanding Simple Past Tense and Present Perfect Tense. Jurnal Online Mahasiswa (JOM) Bidang Pendidikan Bahasa Inggris, 1(1).

Tsay, M., \& Brady, M. (2010). A Case Study of Cooperative Learning and Communication Pedagogy: Does Working in Teams Make a Difference?.

Journal of the Scholarship of Teaching and Learning, 10(2), 78-89. 


\section{ENGLISH BORROWING USAGE ON AUTOMOTIVE RUBRICS IN INDONESIAN MOTOBLOGS}

(A Morphological and Semantics Analysis)

\section{A RESUME}

Submitted to English Education Study Program of Suryakancana University in Partial Fullfilment of the Requirements for the Sarjana Pendidikan Degree

by

Dimas Kusnadiaji

$\mathbf{8 8 2 0 3 1 3 0 5 5}$

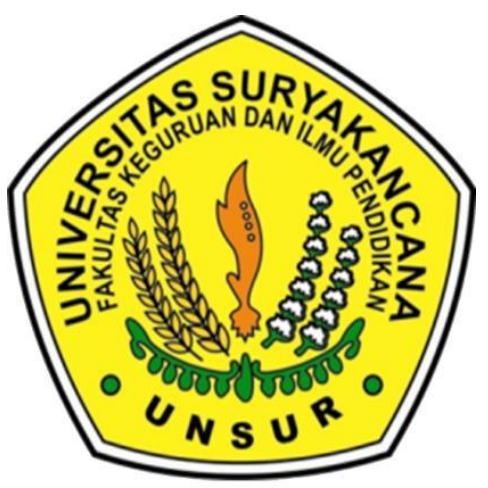

ENGLISH EDUCATION STUDY PROGRAM

FACULTY OF EDUCATION AND TEACHER TRAINING

SURYAKANCANA UNIVERSITY

CIANJUR

2017 


\begin{abstract}
This research concerns on the use of English Borrowing in the automotive article in Indonesian Motoblogs. Apart from that, there is an attempt to find out the dominate English Borrowing words that used by the article author, the reasons of an article author that used English Borrowing words in writing their article. The research was conducted by using qualitative method which is the source of data are the texts in the article of motoblogs (TMCblog.com, IwanBanaran.com, and Kobayogas.com), in collecting the data the researcher obtains the data by observing the word considered as English borrowing word from certain motoblogs, doing open ended interview to the author of motoblogs through email, and analyze every couple data with brief description based on Malmkjaer theory. The research findings showed that the types of English borrowing word that usually used by the author of automotive blog is dominated by Pure Loanword, and the reason of the author of automotive blog in applying English borrowing word in writing their article is because there is no equivalent word to shown or explain the author idea in writing the article, to shortening the word or sentence without discard the meaning, the last reason because English word are briefer and to the point in revealing the exact meaning. The researcher provide several suggestions, for lecturers it suggested could apply English borrowing word wisely especially in Morphology and Semantics class, and for students suggested that they can improve their skills and abilities in using and analyzing English Borrowing word that already used in morphology and semantics class.
\end{abstract}

Keywords: Borrowing, Motoblog, Internet, Mass Media Online. 


\begin{abstract}
ABSTRAK
Penelitan ini terpusat pada penggunaan Kata Pinjaman B.Inggris pada artikel otomotif di blog-blog motor Indonesia. Tak hanya itu penelitian ini juga bermaksud untuk menemukan dominasi Kata Pinjaman Bahasa Inggris yang digunakan oleh para penulis artikel, juga alasan dari para penulis untuk menggunakan Kata Pinjaman Bahasa Inggris dalam menulis artikel mereka. Penilitian ini dilakukan dengan menggunakan metode kualitatif yang sumber datanya adalah seluruh teks pada artikel di blog-blog motor (TMCblog.com, IwanBanaran.com, dan Kobayogas.com), dalam mengumpulkan data peneliti melakukan observasi terhadap kata yang merupakan kata pinjaman Bahasa Inggris dari beberapa blog motor, peneliti juga melakukan wawancara secara terbuka kepada para penulis artikel blog motor melalui surel elektronik/email, dan menganalisa setiap data dengan penjelesan menyeluruh yang berdasar kepada teori Malmkjaer. Penemuan dari penelitian ini menunjukan bahwa tipe Kata Pinjaman Bahasa Inggris yang sering digunakan oleh penulis blog motor di dominasi oleh Pure Loanword (kata pinjaman yang sesuai dengan bentuk aslinya), dan alasan para penulis blog motor dalam menggunakan Kata Pinjaman Bahasa Inggris ini karena tidak ditemukannya kata yang sesuai atau tidak ada padanan kata yang sesuai untuk menjelaskan ide para penulis dalam menulis artikel, alasan kedua adalah untuk mempersingkat kata/kalimat tanpa menghilangkan arti yang sesungguhnya, dan alasan yang terakhir karena Kata Pinjaman Bahasa Inggris lebih jelas dan mengacu pada poin inti dari sebuah penjelasan. Peneliti memberikan beberapa saran, untuk para dosen peneliti menyarankan agar mengaplikasikan Kata Pinjaman Bahasa Inggris dengan bijak utamanya pada kelas Morfologi dan Semantik, dan untuk para siswa disarankan agar dapat meningkatkan kemampuan mereka dalam menggunakan dan menganalisa Kata Pinjaman Bahasa Inggris pada kelas morfologi dan semantik.
\end{abstract}

Kata Kunci: Pinjaman, Blog Motor, Internet, Media Online. 


\section{Introduction}

Every language in the world will experience a change, that phenomenon is natural and very general, as long as human used it as a tool for communication. It is in line to Fasold \& Linton (2006) statement said that "language change happened because they are used by human beings not machines. Human share common cognitive and psychological characteristic, but members of speech community differ slightly in their knowledge and use of their shared language".

The globalization also has important influence in language change. The existence of various languages in the world has made it possible for them to interact and contacted each other. Newspaper, magazines, movie, radio, social site, are the media of that language or contact. When Indonesian people listen to the English songs, listening the lecturer explain the material in English, or read some English lecture book, both of English and Indonesian language are contacting each other. According to Jendra (2010), language contact is a social circumstance where two or more languages, element of different language, or variety within a language, used simultaneously or mixed one of the others.

Usually, the greatest influence comes from language that dominated the world. In this case English language refers to the dominant language that used in global era. Crystal (1997, p.106) said that "English is now dominant language or official language in over 60 countries and is represented in every continent". English as a foreign laguage, which is recognized as an international language, Indonesia is one of the countries that apply some words from English as a consequence of language contact that called borrowing.

Now a days, the use of borrowing word can be found in every thing that having to do with it, such as in education concept, politics, and mass media and many more, some of examples of borrowing word that used in automotive blogs is Test Ride Suzuki GSX-S 150, Spy Shot Yamaha Vixion 2017, Motor Sport Fairing 150cc. Based on the examples above ther is a tendency of the writers to use English borrowing words in their writing rather than to use Indonesia, because ther are some of English borrowing words that have the same meaning in Indonesian vocabularies. For example word Test Ride translating into Percobaan 
Mengendarai, Sport translating into Olahraga, Spy translating into Mata-mata (Moeljadi et al., 2016). The language that used in mass media or sometimes in education should be more easily to understand by the reader, to avoid the different interpretations that can lead and build public opinion. According to Badudu (1988) the journalistic language have very special characteristics, such a short, dense, simple, smooth, attractive and clear.

Relying to the background above, the researcher inteds to analyze the usage of English borrowing words on Automotive Rubrics in Indonesian Motoblogs.

Based on the background the writer conducts the study aim is to answer 2 research questions of this study:

3. What type of English borrowing words that usually used by the writer (automotive blogger) in writing the article?

4. Why English borrowing words are used by the writer (automotive blogger) in writing their article?

\section{Literature Reviews}

\section{a) The Definition of Borrowing}

Borrowing is one of language phenomena caused by language contact. As stated by Hoffer $(2005$, p.1), "Borrowing is the process of importing linguistic items from one linguistics system into another, a process that occurs any time two cultures are in contact over a period of time". In line with Hoffer, most linguists also prefer to deal with the term of borrowing or also known as loanwords that are words which are imported from one language and taken by another (Haugen, 1950, p.212).

Borrowing is a general phenomenon and have been a global phenomenon. Even English has borrowed the word to enrich their vocabularies from different sources. Jendra (2010, p.82) said "English has enriched 75 percent of its lexicon through borrowing from different sources. It shown us that even English have supplied word from German (Kindergarten, seminar), Italian (piano, casino, extravaganza, cappucino, pizza), Spanish (macho, mosquito, cannibal, or tornado). 
Indonesian language also has enriched their lexicon from different sources, one of the result can be seen in the vocabulary. It happened because in addition to give a name for the new concepts, the borrowing also is one way to enrich vocabulary. Related to the statement above. Wardaugh (1972, p.209) stated that borrowing added new vocabulary items to language. It means that new words are needed to give a name to the emergency of new object, new concept and new ideas. In naming process, it should be borrowed from other language to create the new one. It happens when no such word found in the recipient language. This is rarely done because to become a reach language, scientific language and language of culture, the recipient of the language have to borrow the word and enrich the vocabularies.

\section{b) Types of Borrowing}

Katamba (2005, p.134) proposed classification on borrowing words based on the formation of words, and also classified borrowing into three types, namely loanwords, loanblends and loanshift. The first is loanwords, Katamba (2005, p.134) stated that "loanword is a word belonging to one language which is imported or adapted by another language: otherwise they are generally considered foreign words". The second is loanblends, according to Hocket (1958; cited in Hoffer, 2005, p.54) that said "A loan-blend is a form in which one element is a loanword and the other is native element, as in the borrowed preost (priest) plus the native -had (hood) in Old English to produce preosthad (priesthood)." In the other hand, loanblend occur when the meaning of a word is borrowed but only part of the form." (Baker \& Jones, 1998, p.165), and the third as the last is loanshift, it is a borrowing that takes place in a process of adapting the borrowed words into the new meaning, in line with this Hocket (1958, p.53) stated that good example from the early Christian era in England is Easter, which had earlier been used for a pagan dawn goddes festival. Other loanshifts in English include God, heaven, and hell. According to Apple \& Muysken (2005, p.164) that stated the simplest case, a word is first borrowed as a whole: both sound and meaning. In the first process of borrowing, the first word is borrowed as a whole: both sound and meaning but this view has been changed for over period time because the 
recipient language has an own syntactic rule to change the word. It means the words will change: both of phonemics or of the grammatical system.

\section{c) Reason of Borrowing}

According to Katamba (2005, p.136) argues that the reasons for borrowing from foreign languages, the most obvious and maybe also the most reflective one is the introduction of new concepts for which there are no suitable words in the task language, not only that, at various periods in world history different civilizations have been distinguished in one field or another (like for example sciences, trade, military, and medicine). Not only that, the normal course of development was then that the language of this civilization became the lingua franca for that specific field during the period of their pre-eminence.

This also reflected by the concentration of borrowings in certain semantic fields from that language to other. In the middle Ages the Arabic world was advanced in many sciences and thus, a lot of words have been passed on during this time to other languages and also to English. Some of the best known examples are alchemy, alcohol, and algebra. Many of those Arabic terms have not been borrowed directly into English, but were gradually passed on to English from other languages. According to Katamba $(2005$, p.137) that mention the typical way that many scientific Arabic words took. English often acquired them from French, which took them over from Spanish and Spanish finally had borrowed them directly from Arabic.

\section{d) Internet}

The internet, sometimes called simply the Net, it is a world wide system of computer networks - a network in which user at any one computer can, if they have permission, get information from any other computer. It was considered by the Advanced Research Projects Agency (ARPA) of the U.S. government in 1969 and was first known as the ARPANET (Katarzyna, 1999).

More information about internet is the network that enables to communicate with each other and transfer data remote distance, this is wirelessly, via wires and fiber optic cable (Johansen, 2017). In addition, internet can be defined as an exchange of information and communication internet also provides 
opportunity for everybody in the world to get information and communicate instantly. Therefore, space and distance doesn't become limitation anymore.

\section{e) Mass Media Online}

The world of communication has changed drastically since the Internet revolution era, primarily due to such computer innovators as Jobs and Gates. In the future, the names Steve Jobs and Bill Gates will have much significance to them. The development of the World Wide Web and its access to information from around the world has also had a strong impact on all forms of the more traditional media.

Today, computer users can listen and watch both live and recorded news and sports reports from sources as ABC, CBS, ESPN, and NBC. After a high-tech California based company developed the first video search, people could view segments from news conference or events by simply typing a phrase or keywords into the search engine. Also, there are over 2.400 radio stations around the world that are already sending their programming out by way of the internet, allowing people to tune in with the click of a mouse (Salah, 2013).

Not only that, this new technology boosts their ranks of listeners and also allows them to sell more advertising. Next, one positive effect that the internet has had on journalism is the ability to get information out to audiences quicker. With search engines like Google and info seek, people are able to obtain a wide variety of information like news, sports, entertainment, and business that is updated around the clock.

\section{Motoblog/Automotiveblog}

Chi (2010) stated that blog is an abbreviation of "web log" which is a type of website or part of a website. In line with that, blog mainly refers to the website maintained by an individual, in this blog he or she can write something like describe some events taken place in his life, record his own feeling about something, comment or discuss the news or any other things or ideas. He or she also can put pictures, videos or others in his or her blog and even links. So many blogs that provided in the internet including motoblog / automotive blog, in this blog usually consist of features research, news and reviews, videos, a forum, and 
more for all things automotive. The visitors can search new or used car/motorcycle by make, model, and style. In Indonesia, there are lot of automotive blog that already exist, such as TMCblog, Mazpedia, Otomania, Kobayogas.com and many more.

\section{Method}

The research is using descriptive qualitative research as a framework of the study. Fraenkel \& Wallen (1990, p.380) stated "qualitative research is employed in collecting, analyzing, and interpreting data by observing what people do and say", In addition According to Moeleong (1989, p.3) stated that "Qualitative Research is a research procedure that represent the descriptive data such as words in written and oral form".

The researcher tried to describe and analyze the word from the writings posted in automotive rubrics in Indonesian motoblogs such as (TMCblog.com, IwanBanaran.com, and Kobayogas.com). The words are classified into the data needed for the analysis. This is an important step, where the words considered as data are obtained by using the existing theory. The data are analyzed. Finally, the researcher interprets and portrays the reason of the motoblogs author using English borrowing words on their article.

\section{a) Data Source}

The sources of data for this research are the texts and pictures in the article of motoblogs. The main data of this research are the texts on motoblogs posting section in March 2017 until April 2017 by doing reading and studying in the internet connected with certain website (TMCblog.com, IwanBanaran.com, and Kobayogas.com). The researcher limited only one month is because the activity writing publishes sections are more advance in March 2017 to April 2017.

The secondary data are by doing open-ended interview through email between the researcher and the author of certain motoblogs (TMCblog.com, IwanBanaran.com, and Kobayogas.com). The steps are overviewed as follows:

1) Clicking several motoblogs that already chosen in Mozilla Firefox or Google Chrome. 
2) Selecting and downloading the profile page containing the selected words that were posted from March 2017 to April 2017.

3) Sending message via email to ask the author of certain motoblogs (TMCblog.com, IwanBanaran.com, and Kobayogas.com) reason regarding their habit in using English borrowing word in writing their article.

\section{b) Data Collection}

In collecting the data, the researcher obtains the words by observing data that considered as English borrowing word from certain motoblogs (TMCblog.com, IwanBanaran.com, and Kobayogas.com). There is several phases that applied by the researcher in selecting the words considered as English borrowing words, that will be described as follow:

3. Converting the posting page presented in html type into word document by copy pasting the whole part of posting page section.

4. Separating the writing which contains emoticon and non-English words, such as Javanese, Indonesian, Mandarin, etc. Because the words which will be analyzed are English borrowing words.

5. From the writing texts, the writing on the article that containing English borrowing words are obtained. The researcher taking the words considered as English borrowing words.

\section{c) Data Analysis}

In this research, the researcher analyzes the data based on Malmkjaer (1995, p.170) theories which are:

1) Redacting the data. This is the first component in analyzing the data that contains selection process, focusing, and summarizing data from field writing, In this step, the researcher select, limits, and summarize the data from the writing. The researcher identifies the words considered as English borrowing word from the authors of motoblog writing and then the words identified by consulting dictionary to find the meaning of the words. In this case, the researcher used Oxford Advanced Learner Dictionary 3rd edition. After that the researcher categorized the English borrowing into pure and modified loanwords. 
2) The researcher classified the English borrowing words into the category considered as types of borrowing by using the rule that stated by Eignar Haugen there are loanword, loanblend and loanshift.

3) Displaying the data. The second step of analyzing the data is describing the data in narrative which the research conclusion will be possible to be done. This step is describing the result of the research which is described in systematic and logic sentence. The researcher analyzed the answer of motoblog author's reason and classified the answer into some factor that influences the respondent to use English borrowing word.

4) Drawing Conclusion. The last step is the researcher makes conclusion of the research. Then the researcher also verifies the conclusion the technique is by discussing the research. This step is very important to be done in order to get good research conclusion.

\section{Result and Finding}

a) The Types of English Borrowing Words that Usually Used by the Author

\section{of Automotive Blogs}

According to the data finding that obtained, the type of English borrowing usage that usually used by the author of certain motoblogs (TMCblog.com, IwanBanaran.com, and Kobayogas.com) is dominated by Pure Loanword, from 50 (fifty) English borrowing word that obtained, the researcher find 40 (forty) Pure Loanword used/applied by the authors of motoblogs in writing their article, which is imported/borrowed identically with the original form in English (native word), the words itself are imported/borrowed without any changes of word class, category and meaning.

Talk about another types of English borrowing usage, the researcher find 7 (seven) Loanblend which is borrowed by the authors of motoblogs in writing their article, there is a morphological adjustment to the words and also there is an adjustment of Indonesian affixes and semantically that adjustment affected to change the word class, category, and meaning. And the last English borrowing 
word that applied/borrowed by the authors of motoblogs is Loanshift, the researcher find 3 (three) loanshift that imported/borrowed by the author in writing the article, the words are totally changed in structure, but the meaning of that word are originally extracted/maintained.

\section{b) The Author Reason in Applying English Borrowing Word in Writing an Automotive Article}

Based on the data that gained from the interview to the automotive blogger that using and applying English borrowing word, there are some different reason from each author of automotive blogs that applying/borrowing the English word in writing the article, the first reason is because there is no equivalent word to shown or explain the author idea in writing the article. It is stated by the author of TMCblog.com. So that's why the author imported or borrowed the English word.

Different with the author of Kobayogas.com that stated the second reason. It is because the author try to shortening the word or sentence but didn't discard the meaning, the author of Kobayogas.com also stated another reason, the author argued when some word are converted into Indonesian language, it's become weird.

And the third reason is revealed by the author of Iwanbanaran.com, the author assume that English word are briefer and to the point, even somebody didn't understand the meaning it consider to the context of that word, and if somebody concerning to that aspect, automatically they can understand the exact meaning.

\section{Conclusion}

The result of this study will be concluded by the researcher as follow:

According to the data finding that obtained and discussed in Chapter IV, it can be concluded that the type of English borrowing usage that usually used by the author of certain motoblogs (TMCblog.com, IwanBanaran.com, and Kobayogas.com) is dominated by Pure Loanword, from 50 (fifty) English borrowing word that obtained, the researcher find 40 (forty) Pure Loanword 
used/applied by the authors of motoblogs in writing their article, which is imported/borrowed identically with the original form in English (native word), the words itself are imported/borrowed without any changes of word class, category and meaning. In the other hand, another types of English borrowing that used, the researcher find 7 (seven) Loanblend which is borrowed by the authors of motoblogs in writing their article, there is a morphological adjustment to the words and also there is an adjustment of Indonesian affixes and semantically that adjustment affected to change the word class, category, and meaning. And the last English borrowing word that applied/borrowed by the authors of motoblogs is Loanshift, the researcher find 3 (three) loanshift that imported/borrowed by the author in writing the article, the words are totally changed in structure, but the meaning of that word are originally extracted/maintained.

Based on the data of the interview to the automotive blogger that using and applying English borrowing word, there are three different reason from each author of automotive blog in using English borrowing word in writing the articles, the first reason is because there is no equivalent word to shown or explain the author idea in writing the article, the second is to shortening the word or sentence but didn't discard the meaning, and the last reason because English word are briefer and to the point in revealing the exact meaning. 


\section{BIBLIOGRAPHY}

Apple, R. \& Muysken, P. (2005). Language and Contrast Bilingualism. London: Amsterdam University Press.

Badudu, JS. (1988). Cakrawala Bahasa Indonesia. Jakarta: Gramedia.

Baker, C. \& Jones, P, S. (1998). Encyclopedia of Bilingualism and Bilingual Education. British Library UK: Multilingual Matters Ltd.

Chi, M. (2010). Social Media Commercialization and Blog Marketing. Sweden: Stockholm.

Crystal, David. (1997). The Cambridge Encyclopedia of the English Language. Cambridge: Cambridge University Press.

Fasold, R \& Lington, C. (2006). An Introduction to Language and Linguistics. Washington DC: Georgetown University.

Fraenkel, J., \& Wallen, N. (1990). How to Design and Evaluate Research in Education. New York: McGraw-Hill Pub.Co.

Hocket, C.F (1958). A Course in Modern Linguistics. New York: Macmillan.

Jendra, I. (2010). Sociolinguistics. Bali: Graha Ilmu.

Katamba, F. (2005). English Words. USA and Canada: Routledge.

Malmkjaer, K. (1995). Linguistics Encyclopedia. London \& New York: Routledge.

Moeleong, L (1989). Metode Penelitian Kualitatif. Bandung: PT Remaja Rosdakarya.

Moeljadi, D., Sugianto, R., Hendrick, S, J. \& Hartono, K. (2016). Kamus Besar Bahasa Indonesia, (5th ed), Jakarta: Badan Pengembangan dan Pembinaan Bahasa, Kementrian Pendidikan dan Kebudayaan Republik Indonesia.

Wardhaugh, Ronald. (1972). An Introduction to Sociolinguistics. New York: McGraw-Hill. 


\section{JOURNALS}

Hoffer, B.L. (2005) Language Borrowing and the Indices of Adaptability and Receptivity. Intercultural Communication Studies XIV-2, pp. 53-77.

Haugen, E. (1950). The Analysis of Linguistic Borrowing. Language, 26:210-31. 


\section{WEBSITES}

Salah, C. (2013). Internet and Mass Media. Retrieved April 6, 2017, from:

www.uri.edu/students/csal6499/internet.html

Katarzyna, J, M. (1999). Internet for You. Retrieved April 6, 2017 from:

www.rsna.org/Technology/internet1-1.cfm.

Johansen, T. (2017). Internet. Retrieved April 6, 2017, from: www.diaryofanartist.com 


\title{
DEVELOPING LISTENING FOR GENERAL COMMUNICATION COURSEBOOK FOR THE FIRST SEMESTER STUDENTS OF STKIP SILIWANGI BANDUNG
}

\author{
Lilis Suryani \\ suryani.lies3@gmail.com \\ Ningtyas Orilina Argawati \\ tyas.orilina@yahoo.com \\ STKIP Siliwangi Bandung
}

\begin{abstract}
Listening is one of compulsory subjects for the students of English education study program of STKIP Siliwangi Bandung. It is taught at the first semester as a basic for the students to enhance others skills, such as speaking, reading, and writing. In fact, the students face problems in learning listening and it makes the objectives of learning do not achieve well. So, this research is aimed at creating listening course book to help the students learn effectively. This research focuses on listening for general communication. The research employed Research and Development. This method is divided into three parts; introductional study covers need analysis, literature review, proposal arrangements, and prototype;product developmentcovers materials arrangement and course book arrangement;and testinginvolves validation from expert, and revision. The subject of the research is the first semester students of English education study program of STKIP Siliwangi Bandung. The instruments used were interview and questionnaire. Interview was conducted to gather the data related with the themes used in the course book in every unit. There were six themes obtained through the interview.
\end{abstract}


Then the themes chosen were developed based on the material guideline composed by the researcher in the previous research which cover macro and micro skill. Next is validation by three experts using questionaire. The revison covered the content, display and language, then the test was re-taken to gather the feasible of the coursebook. From the computation, the mean score of content hit the precentage of 79.17, while display was 77.78 and language was 77.5 . from the resut, the researchers could assume that the course book was feasible and ready to use in teaching and learning of Listening for General Communication Key words: listening for general communication, course book. $R \& D$.

\section{A. Introduction}

Listening becomes a crucial part of communication. It is the first skill received by persons and it is not an easy way to understand listening as a part of communication, especially when they are not the native speakers. This is in line with Rost (2011), listening is one of the crucial components of spoken language processing- there is no spoken language without listening. It means that listening is the basic skill to support speaking skill. He also adds that listening is receptive skill and it is receiving the transfer of images, impressions, thoughts, beliefs, attitudes, and emotions from the speaker. It is supported by Underwood (1993), 'listening is the activity of paying attentionto and trying to get meaning from something we hear'. In other hand, listening transfers and understands information from the speaker to the listener.

Listening skill is one of compulsory subjects that have to be taken by the students of STKIP Siliwangi Bandung, especially English education study program. Nevertheless, the students still have problems in acquiring the materials of listening, such as the materials are not suitable with the students' ability, and the students have various abilities (Argawati and Suryani, 2016). 
This research is further research; the researchers have already conducted the previous research about the guideline of listening for general communication. The guideline is used as a guideline for the lecturers in teaching listening for general communication. This research would like to develop more about the materials of listening for general communication and create listening course book in teaching listening for general communication based on the guideline of listening.

Creating text book is helping the students to know the materials easily. According to Beare (2011), choosing the right course book is one of crucial tasks that teachers need to carry out. Course books have gradually become important for language instruction. The same way goes to teaching listening. Harmer (2007) explained that using course books creatively is one of the teacher's premier skills. So, the teachers play an important part to decide the good course books for the students. By those definitions above, the researchers come to the conclusion that a course book is a book which specially designed to help the students to improve their knowledge and support their language activities in the classroom. Therefore, this research would like to create listening course book in order to help the students in learning listening, especially listening for general communication.

\section{B. Theoretical Review}

Listening is a receptive skill that students should learn in the classroom. According to Broughton, et al (1980: 65), listening calls for active participation in the communication between the participants and a receptive skill is involved in understanding the message. In addition, Rost (2011) stated listening is receiving fresh attention as an active skill that can be taught directly. In other words, listening is not a passive skill because it needs interaction to understand the meaning.

Brown (2001) stated that without listening we cannot produce the language. It indicates that listening is the first basic skill and it has important role in developing others language skill of the students, such as speaking, writing, and reading. In addition, Roskos, Christie and Richgels (2003) said 
that listening is the one that develops earliest and is practiced most frequently. Based on those statements above, listening is an active skill and it most frequently used by the students. Listening also has an important role in developing students' language skill.

While the purpose of the research is developing a course book of Listening for General Communication. Then, some definitions of course book are going to propose. Course books have gradually become important for language instruction and it helps the teachers in delivering the materials in the classroom. As stated by Richard and Rodgers (2001), course books are an unavoidable element of the curriculum because they specify content and define coverage for syllabus items.

A course book can be referred to as a published book specially designed to help language learners to improve their linguistic and communicative abilities (Sheldon, 1987). In line with Sheldon, Mares (2003) believes that course book is an instrument designed to give cohesion to the language teaching and learning process by providing direction, support and specific language-based activities aimed at offering classroom practice for students.

Cunningsworth (1995:7) also adds that the roles of course book in ELT as :a resource for presentation materials, a source of activities for learner practice and communication interaction, a reference sources, a syllabus, a resource for self-directed learning or self-access work, and a support for less experienced teachers.

By those definitions above, the researchers come to the conclusion that a course book is a book which specially designed to help the students to improve their knowledge and support their language activities in the classroom. Besides, teachers teach the materials easily.

\section{Research Method}


Research and Development ( R and D) was used as a method of the research. As stated by Borg and Gall (1983) in Argawati and Suryani (2016), Research and Development (R\&D) is a process used to develop and validate educational products. The product developedin this research was a course book of Listening for General Communication which has been aimed to be used in teaching and learning activity of this subject.

The procedures of applying this research method consisted of three steps. The steps are: introductional studycovers need analysis, literature review, proposal arrangements, and prototype;product developmentcovers materials arrangement and course book arrangement;and testinginvolves validation from expert, and revision (Sukmadinata, 2006)

The procedures in detail can be seen in chart 1 below.

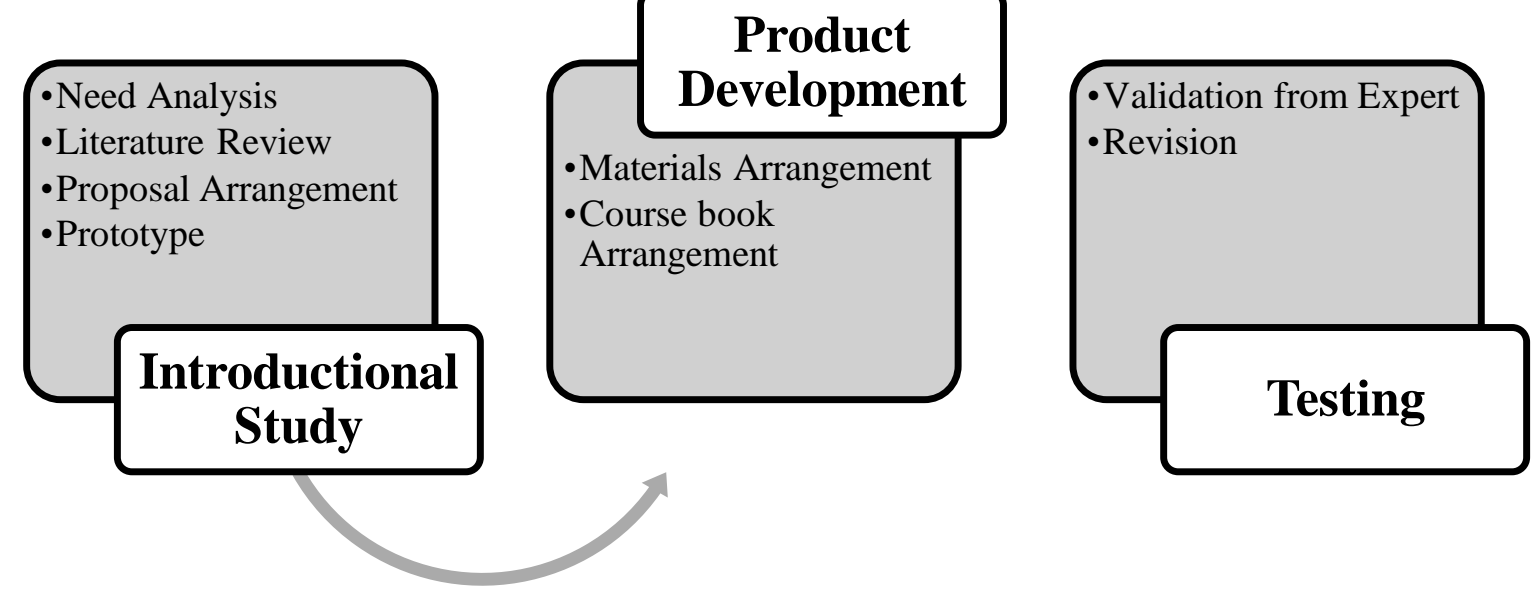

Chart 1. Procedures of $\mathrm{R}$ and $\mathrm{D}$

The subject of the research was the first year students of English Study Program of STKIP Siliwangi Bandung. The subject was determined using purposive sampling. The data collected in this research cover qualitative and quantitative data. Qualitative data comes from observation, questionnaire, interview and field note from previous research. Meanwhile, qualitative data are gathered from testing the product through the implementation of the 
product in the classroom. This testing includes pre and post test. There are two kinds of data gathered in this research; qualitative and quantitative data. Qualitative data would be analyzed descriptively. While quantitative data would be analyzed to gain the valid data.

\section{Result and Discussion}

The research was started by doing introductional study. In this phase, the researchers prepare the guideline of material development which had been compiled on the previous research conducted by the researcers (Argawati \& Suryani, 2016). The guideline contains several aspect of listening which have to be included in the coursebook developed. The aspects of listening were taken from several experts, then the researchers made such a conclusion towards the aspect gatheredfrom the experts.

From the conclusion, the researchers proposed some aspect of listening which were used in this research as seen in table 1:

Table 1

Aspect of Listening

\begin{tabular}{lcccc}
\hline \multicolumn{1}{c}{ Rubin } & Barney & Underwood & Brown & Aspects \\
$(\mathbf{1 9 9 4 :}) \mathbf{2 1 0})$ & $(\mathbf{1 9 8 4 )}$ & $(\mathbf{1 9 9 3 : 1 )}$ & $\mathbf{( 2 0 0 4 : \mathbf { 1 2 1 } )}$ & \\
\hline A process of & something we & Recognizing the \\
decoding the & hear & distinctive sounds \\
sounds & & &
\end{tabular}

$\begin{array}{ll}\text { interact with a get meaning } & \text { Use facial, kinesics, Understandmeaning } \\ \text { speaker } \quad \text { to } & \text { body language, and } \\ \text { construct } & \text { other nonverbal } \\ \text { meaning } & \text { clues to decipher } \\ & \text { meanings }\end{array}$

a highly- the activity of Recognize the Responding the 


\begin{tabular}{|c|c|c|c|}
\hline complex solving & paying attention & communicative & communicative \\
\hline activities & to & functions. & function: situation, \\
\hline & & & $\begin{array}{l}\text { participants, and } \\
\text { goals }\end{array}$ \\
\hline context & & Infer situations, & Inferrencingliteral \\
\hline experiences and & & participants, goals & implied \\
\hline knowledge & & using real-world & meanings, \\
\hline & & knowledge & information, given \\
\hline & & & information, main \\
\hline & & & supporting \\
\hline & & & idea \\
\hline & & Develop and use a & Guessing \\
\hline & & battery of listening & cohessive \\
\hline & & guessing & and \\
\hline & & meaning of words & grammatical \\
\hline & & from context & classes. \\
\hline
\end{tabular}

1. Recognizing the distinctive sounds

The aspect being developed is recognizing the distinctive sound. The material could be something relate with defferentiating sounds. For example, students are given list of words containing various minimal pairs (a pair of word or may be more than two words which have the same and similar sound).

2. Understanding meaning

The aspect being developed is understanding the meaning. From the text spoken by the speaker, the students have to know and understand the meaning. This aspect is closely related with the first aspect. If the 
students are be able to recognize the pronunciation of certain words, they will easily determine the meaning of the words.

3. Responding the communicative function: situation, participants, and goals

The third aspect is responding the communicative function, situations, participants, and goals. If the students are be able to master the two aspects above (recognizing the distinctive sound and understanding meaning), the students are hoped to have ability of responding the comunicative function, situations, participants, and goals.

4. Inferrencing literal and implied meanings, new information, given information, main idea, supporting idea

The fourth aspect is inferrencing the literal and implied meaning, new given information, and main and supporting ideas. The lecturer can also compile a more difficult activity by asking the students to find implicit meaning from the context. Here, the full text is given attached with several question such as, what is the topic or main idea of the text, who is the speaker, where does the conversation take place, etc. These kind of questions enable the students to listen more carefully to the text spoken by the speaker

5. Guessing words, cohessive devices and grammatical word classes.

The last aspecttaken is guessing the words, cohesive devices and grammatical word classes. In this case, the ability of the students which is going to develop is their skill on guessing the meaning through context using cohesive devices and grammatical word classes.

Beside the aspects of listening, the researchers also took the micro and macro skills into account. The macro and micro skills werethen devided into their characteristics based on the aspect proposed. The macro and micro skills of listening are presented in the table 2 below:

Table 2

Macro and micro skills oflistening 


\begin{tabular}{|c|c|c|}
\hline No & Aspects & Micro and macro skill \\
\hline 1. & $\begin{array}{l}\text { Recognizing the } \\
\text { distinctive sounds }\end{array}$ & $\begin{array}{l}\text { - Discriminate among the distinctive sounds of English } \\
\text { - Retain chunks of language of different lengths in short } \\
\text { term memory. } \\
\text { - Recognize English stress patterns, words in stressed and } \\
\text { unstressed positions } \\
\text { - rhythmic structures, intonation contours, and their roles } \\
\text { in signaling information } \\
\text { - Recognize reduced forms of words } \\
\text { - Process speech at different rate of delivery } \\
\text { - Process speech containing pauses, errors, corrections, } \\
\text { and other performance variables. }\end{array}$ \\
\hline
\end{tabular}

2. Understanding the meaning

3. Responding the communicative function, situation, participants, and goals

4. Inferrencing literal and implied meaning, new and given information, main and supporting ideas

5. Guessing the Words, cohesive devices and grammatical word
- Distinguish word boundaries, recognize a core of words, and interpret word order patterns and their significance

- Recognize that a particular meaning may be expressed in different grammatical forms.

- Use facial, kinesics, body language, and other nonverbal clues to decipher meanings.

- Recognize the communicative functions of utterance according to situations, participants, goals.

- Infer situations, participants, goals using real-world knowledge.
- Detect sentence constituents and distinguish between major and minor constituents

- From events, ideas, and so on, describes, predict outcomes, infer links and connections between events, deduce causes and effects, and detect such relations as main idea, supporting idea, new information, given information, generalization, and exemplification.

- Distinguish between literal and implied meanings 
The coursebook developed were based on these macro and micro skills above.

The next step the researchers took was doing need analyis. The data gathered were through interview towards five first-year-students of STKIP Siliwangi Bandung to find out the materials which should be covered on the course book. Borg and Gall (1983) stated in Kurniawan (2016: 78) that need analysis refers to activities to collect the data related to previous condition in the field and the expected need to solve the problem. the activities conducted in this stage were gathering some data through interview and observation. The interview done in this research aimed on figuring out the students' interest relates with the material they were going to learn. Besides, it also done to know the condition of the students itself to draw conclusion about their specific needs in the classroom.

The result of the interview from five students showed that the students prefer materials used to be in the coursebook of Listening for General Communication are more about daily conversations or daily topics. They stated that with the familiar materials, they can learn the materials obtimally without facing too much difficulties. Moreover, the determination of the themes used in the coursebook were obtained by using questionnaire.

The themes for this coursebook were determined by using interview to the three lectures and 15 students from three levels. The result of quesstionnaire can be seen in table 3 below:

Table 3

The themes preference based on respondents

\begin{tabular}{ll}
\hline Unit 1 & Getting to know you \\
\hline Unit 2 & People \\
Unit 3 & Public Places \\
Unit 4 & Jobs \\
\hline
\end{tabular}




\begin{tabular}{ll}
\hline Unit 5 & Travelling \\
Unit 6 & Shopping \\
\hline
\end{tabular}

The researchers chose only six themes because they adjust the themes with the meeting during semester. There are 14 meetings to cover the whole coursebook. In this 14 meeting, the students will face many difficulties if they have to finish all of the 14 units. Besides, there is a meeting which is used to conduct midterm test. So that the meetings left are 13 meetings. Based on that data, the researchers took six units to be covered within 13 meetings. It means that, one unit will be covered within two meetings. And for the 13th meeting, the researchers planned to use it as a review meeting. Through these six units, the researchers expect that the students can obtained the knowledge and are be able to train their ability better and thouroughly.

Through the questionnaire towards three lecturers and 15 students from three different level, it could be obtained six themes to be used in the coursebook. Every unit discusses different topics and contain different activities. However, the content of all the units of the coursebook must relate on the aspect and cover the macro and micro skills proposed before in the previous research.

Here are the descriptions of each unit proposed by the researchers.

\section{Theme 1: Getting to know you}

In this unit, the researchers present several materials relate to introduction. This unit provides the students some ways to introduce something. The students will learn about basic language how to introduce themselves. This unit talks about ten sections. Every section is related to guideline of listening course book, such as recognizing the distinctive sounds and meaning.

The first section is talking about two pictures and answering questions based on those pictures. The second section is recognizing the distinctive sounds. The third is listening and writing the correct names. The fourth is saying the phone numbers. The fifth is listening audio and 
filling in the blank. The sixth is matching column A with the right answers in column B. the seventh is describing yourself. The eighth is describing your best friend. The ninth is asking information about your friends. The last is reading.

\section{Theme 2: People}

This unit talks about people, including famous people, friends, and family. This unit covers 11 sections. This theme asks the students' opinion about the most influential people and students' survey. Besides, this unit discusses about family and the meaning of family for the students. It would be interesting topic for the students because they can share information about their family and opinions about people. They can also learn about people who can trigger their motivation to be better people

\section{Theme 3: Public Places}

This unit explains about public places and direction. It covers 10 sections. The students will learn about signs and direction. This theme asks the students to explore public places around them. This unit also provides challenge for the students to make sentences about asking and answering about public places

\section{Theme4: Jobs}

This unit provides the students some terms about jobs. The researchers chose ten unique jobs to attract the students interest. The theme about jobs is such a common topic to study. It consists some definitions of such a job and also present some vocabulary which may be new for the students. The level of difficulty of this unit was also adjusted to the need of the first semester students

\section{Theme 5: Travelling}

In travelling, the researchers tried to serve many different kind of attractive materials. Activities which relate with travelling usually become a good motivation for students. The unit was selected because it contain familiar activities for students. 


\section{Theme 6: Shopping}

The same thing goes to the last unit; it is shopping. This unit really relates with the students' daily life. They do shopping frequently and face some case of shopping aften and almost everyday. That is why the researchers chose this theme.

After the product of listening coursebook had already developed, the next step was to do a validation from experts. The experts chose were three lecturers who teach the subject of Listening for General Communication. The validation sheet covered three several aspect to be reviewed; content, display, and language. The researchers used quesstionnaire and interview to gather the data from those three lecturers. The result of the questionnaire and interview showed that there were still plenty of unproper content contained in this coursebook. The detail result is presented in table 4 below:

Table 4

Result of validation from experts

\begin{tabular}{ll}
\hline Content & 1. The materials in the units are not balance in the way of the \\
activity given. There was one unit which contained 11 \\
activities, but in other unit there were only four activities. \\
2. There are some activities in such unit which did not belong \\
to the theme.
\end{tabular}

The revision made then covers these several things: (1) The reserachers adjust the numbers of activity in each unit in order to balance the content, (2) The researchers eliminate some activity which did not belong to the unit, (3) The researchers adjust the size of all the pictures attached in the book, and the use of colors in every unit, (4) The 
researchers make some correction on miss spelling words found in the course book and replace some of the ambigous words to be more understandable.

From the aspect of content, the coursebook had already covered the five aspects of listening; recognizing the sound, understanding meaning, responding the communicative function, Inferencingliteral and implied meanings, and guessing words, cohessive devices and grammatical word classes. The display of the coursebook had been already served in attractive way with using many kinds of pictures. Then, from the aspect of language, it had fullfilled the readibility test so that the coursebook will not raise missunderstanding. The result of feasibility test of the coursebook is presented in table 4 below.

Tabel 5

\begin{tabular}{lcccc}
\multicolumn{4}{c}{ Feasibility Test Result of the coursebook } \\
\hline No. & Expert & \multicolumn{3}{c}{ Feasibility criteria (\%) } \\
\cline { 3 - 5 } & & Content & Display & Language \\
\cline { 3 - 5 } 1. & Validator 1 & 81.25 & 77.78 & 80 \\
2. & Validator 2 & 79.17 & 75 & 75 \\
3. & Validator 3 & 77.08 & 80.56 & 77.5 \\
& Mean & 79,17 & 77,78 & 77,5 \\
& & & \\
\hline
\end{tabular}

Putra (2016) stated that if the precentage of the aspects is between $63.50 \%-83.00 \%$, it means that the coursebook is feasible to be tested on students. Therefore, the coursebook of listening for General Communication is already ready to be used to the teaching and learning activity.

\section{E. Conclusion and suggestion}


According to the findings of the research, the researchers draw conclusion as follows: Based on the observation and interview from three lecturers and 15 students, they prefer materials used to be in the coursebook of Listening for General Communication are more about daily conversations or daily topics. The themes for this coursebook were determined by using interview to the three lectures and 15 students from three levels as you can see as follows: the first is getting to know you, the second is people, the third is public places, the forth is jobs, the fifth is travelling, and the sixth is shopping.

The researchers chose only six themes because they adjust the themes with the meeting during semester. There are 14 meetings to cover the whole coursebook. In this 14 meeting, the students will face many difficulties if they have to finish all of the 14 units. Besides, there is a meeting which is used to conduct midterm test. So that the meetings left are 13 meetings. Based on that data, the researchers took six units to be covered within 13 .

Next is validation by three experts using questionaire. The revison covered the content, display and language, then the test was re-taken to gather the feasible of the coursebook. From the computation, the mean score of content hit the precentage of 79.17, while display was 77.78 and language was 77.5. from the resut, the researchers could assume that the course book was feasible and ready to use in teaching and learning of Listening for General Communication.

Some suggestion thes were proposed for lecturers and further researchers. Lecturers have an important part in teaching and learning process in the classroom, including choosing course book for the students. Therefore, lecturers should determine appropriate course book for the students. Lecturers should choose course book based on the students level and need. It means that choosing course book can determine the sucesss of teaching and elarning process.

For further researchers, further researchers can use this guideline of listening course book as their guideline in developing liistening course book. 
In addition, they can develop the course book in different listening subjects such as listening in professional context, listening for academic purposes, etc.

\section{BIBLIOGRAPHY}

Argawati, N.O and Suryani, L. (2016). Developing material development guideline of listening for general communication. Jurnal Ilmiah P2M STKIP Siliwangi, Vol 3/2, November 2016. ISSN: 2355-9004.

Barney, H. (1984). The role of listening comprehension: A Theoretical Base. Foreign Language Annals, 17(3), 17-29.

Beare, K (2011). How to choose a course book and other classroom materials. Available at: http: //esl.about.com/cs/teachingresources/ht/courseboook.html(May 5, 2017).

Broughton, G. (1980). Teaching English as a foreign language 2th ed. New York: Routledge \& Kegan Paul Ltd.

Brown, H. Douglas. (2001). Teaching by principles. San Francisco: Longman.

Brown, H. D. (2004). Language assessment principles and classroom practices. NY: Pearson Education, Inc.

Cunningsworth , A. (1995). Choosing your course book. Oxford: MacMillan Publisher.

Harmer, J. (2007). How to teach English. England: Longman.

Kurniawan, Dian M. (2016). Developing reading material through themebased learning for technical autimotive students grade XIH at SMK Warga Surakarta. Thesis. Digilib UNS. Retrieved from: http.digilib.uns.ac.id 
Mares, C. (2003).Writing a coursebook.In B. Tomilson (Ed), Developingmaterials for language teaching (pp. 130-140). London: Continuum.

Putra, HD. 2017. Development of Student Worksheets to Improve the Ability of Mathematical Problem Posing. International Journal on Emerging Mathematics Education (IJEME) Vol. 1, No. 1, March 2017, pp. 1-10 PISSN: 2549-4996, E-ISSN: 2548-5806, DOI: http://dx.doi.org/10.12928/ijeme.v1i1.5507

Richard and Rodger.(2001). Approaches and methods in language teaching. New York: Cambridge University Press.

Richard, J. C. (2001). Curriculum development in language teaching. New York: Cambridge University Press.

Roskos, K. Christie, J. and Richgels, D. (2003).The essentials of early literacy instruction. Available at https://www.naeyc.org/files/yc/file/200303/Essentials.pdf( June 6, 2017).

Rost, M. (2011).Teaching and researching listening $2^{\text {nd }}$. Harlow: Longman.

Rubin, J. (1994). A Review of Second Langugae Listening Comprehension Research. The Modern Language Journal, 78(2), 199-221

Sheldon, L. (1987). ETL textbook\& materials: Problems in Education and Development. Oxford: Modern English Publication.

Sukmadinata, dkk. (2006). Metode penelitian pendidikan. Bandung: PT Remaja Rosdakarya.

Underwood, M. (1993).Teaching listening. London: Longman. 
Hasil Interview untuk menentukan tema pada Course book Listening for General Communication

Peneliti melakukan survey kepada tiga orang dosen pengampu mata kuliah tersebut, dan mahasiswa pada tiga tingkat yaitu angkatan 2014, 2015, dan 2016 sebanyak masing-masing lima orang.

Kemudian hasil dari dosen pengampu dan dari mahasiswa disesuaikan dan ditarik kesimpulan.

Hasil survey pada dosen pengampu mata kuliah tersebut kami sajikan dalam tabel 1 berikut:

\begin{tabular}{llll}
\hline Dosen 1 & Dosen 2 & Dosen 3 & \multicolumn{2}{l}{ Kesimpulan } \\
\hline Greeting & Introduction & Getting to know & Getting to know \\
& & you & you \\
Jobs & Professions & Jobs & Jobs \\
Directions & Public Places & Public Places & Public Places \\
Shopping & Shopping & Shopping & Shopping \\
Travelling & Around the world & Travelling & Travelling \\
Family & Friends & People & People \\
\hline
\end{tabular}


In a restaurant

Procedures

Activities

Holiday

Hobbies

Request

Hasilsurveimahasiswapadatiapangkatandisajikansecaraberturut-turutdalamtabel 2, 3, dan 4 sebagaiberikut:

Tabel 2

HasilSurveipadaMahasiswaangkatan 2014

\begin{tabular}{|c|c|c|c|c|c|}
\hline Mhsswa 1 & Mhsswa 2 & Mhsswa 3 & Mhsswa 4 & Mhsswa 5 & Kesimpulan \\
\hline & Introduction & Greeting & Introduction & Introduction & Introduction \\
\hline \multirow[t]{3}{*}{ Hobbies } & & $\begin{array}{l}\text { Favourite } \\
\text { things }\end{array}$ & Hobbies & & \\
\hline & School & School & School & School & School \\
\hline & & Shopping & Shopping & & Shopping \\
\hline Travelling & Travelling & Travelling & $\begin{array}{l}\text { Travelling } \\
\text { Describing } \\
\text { things }\end{array}$ & Travelling & Travelling \\
\hline Jobs & & Jobs & Professions & Jobs & Jobs \\
\hline Family & & Family & Family & Family & Family \\
\hline \multirow[t]{2}{*}{ Home } & Home & & Daily & Daily & \\
\hline & & & Activities & Activities & \\
\hline $\begin{array}{l}\text { How to do } \\
\text { something }\end{array}$ & $\begin{array}{l}\text { How to do } \\
\text { something }\end{array}$ & & Procedures & Procedures & \\
\hline
\end{tabular}




\begin{tabular}{|c|c|c|c|c|c|}
\hline $\begin{array}{l}\text { Asking } \\
\text { directions }\end{array}$ & & \multicolumn{2}{|r|}{ Directions } & Directions & \\
\hline \multicolumn{6}{|c|}{ Tabel 3} \\
\hline \multicolumn{6}{|c|}{ HasilSurveipadaMahasiswaangkatan 2015} \\
\hline Mhsiswa 1 & Mhsiswa 2 & Mhsiswa 3 & Mhsiswa 4 & Mhsiswa 5 & Kesimpulan \\
\hline Getting to & Introduction & & Introduction & Greeting & Introduction \\
\hline \multicolumn{6}{|l|}{ know you } \\
\hline Hobbies & & $\begin{array}{l}\text { Favourite } \\
\text { things }\end{array}$ & Hobbies & & Hobbies \\
\hline Schools & School & School & School & School & School \\
\hline Shopping & Shopping & Shopping & Shopping & Shopping & Shopping \\
\hline Travelling & Travelling & Travelling & Travelling & Travelling & Travelling \\
\hline Describe & & & Describing & & \\
\hline people & & & things & & \\
\hline Jobs & Professions & Jobs & Professions & Jobs & Jobs \\
\hline Family & Friends & Family & Family & Family & Family \\
\hline \multirow[t]{4}{*}{ Home } & & & & Daily & \\
\hline & & & & Activities & \\
\hline & $\begin{array}{l}\text { How to do } \\
\text { something }\end{array}$ & Procedures & & & \\
\hline & $\begin{array}{l}\text { Ask } \\
\text { directions }\end{array}$ & Directions & Directions & & Directions \\
\hline
\end{tabular}

Tabel 4

HasilSurveipadaMahasiswaangkatan 2016 


\begin{tabular}{|c|c|c|c|c|c|}
\hline Mhsiswa 1 & Mhsiswa 2 & Mhsiswa 3 & Mhsiswa 4 & Mhsiswa 5 & Kesimpulan \\
\hline Greeting & Greeting & Greeting & Introduction & Greeting & Introduction \\
\hline \multirow[t]{3}{*}{ Favourite } & Favourite & Hobbies & & & Hobbies \\
\hline & things & & & & \\
\hline & & School & School & School & School \\
\hline Shopping & Shopping & & & Shopping & Shopping \\
\hline \multirow[t]{4}{*}{ Travelling } & Around the & Travelling & Travelling & Travelling & Travelling \\
\hline & world & & & & \\
\hline & Describe & Describe & Describe & Describing & \\
\hline & people & people & people & things & \\
\hline Jobs & Professions & Jobs & Professions & Jobs & Jobs \\
\hline Family & Friends & Family & Family & Family & Family \\
\hline \multirow[t]{2}{*}{ Home } & & & & Daily & \\
\hline & & & & Activities & \\
\hline \multirow[t]{2}{*}{ Procedures } & & How to do & Procedures & How to do & \\
\hline & & something & & something & \\
\hline \multirow[t]{2}{*}{ Directions } & Ask & Directions & Directions & & Directions \\
\hline & directions & & & & \\
\hline
\end{tabular}

\section{HASIL UJI KELAYAKAN ISI TERHADAP BUKU AJAR LISTENING FOR GENERAL COMMUNICATION}

Instrumen I = Kelayakan Isi

\begin{tabular}{|c|c|c|c|c|}
\hline \multirow{2}{*}{ KOMPONEN } & \multirow{2}{*}{ BUTIR } & \multicolumn{3}{|c|}{ Skor } \\
\cline { 3 - 5 } & & Validator 1 & Validator 2 & Validator 3 \\
\hline A. Cakupan Materi & 1. Keluasan materi & 3 & 3 & 4 \\
\hline
\end{tabular}




\begin{tabular}{|c|c|c|c|c|}
\hline & 2. Kedalaman materi & 2 & 4 & 4 \\
\hline \multirow{5}{*}{$\begin{array}{l}\text { B. Keakuratan } \\
\text { Materi }\end{array}$} & 3. Keakuratan fakta & 4 & 3 & 3 \\
\hline & 4. Keakuratan konsep & 4 & 3 & 3 \\
\hline & 5. Akurasi prinsip/hukum & 3 & 4 & 3 \\
\hline & $\begin{array}{l}\text { 6. Keterkaitan konsep dengan } \\
\text { materi }\end{array}$ & 4 & 2 & 2 \\
\hline & $\begin{array}{l}\text { 7. Keakuratan keterpaduan } \\
\text { indikator }\end{array}$ & 4 & 3 & 4 \\
\hline \multirow{3}{*}{ C. Kemutakhiran } & $\begin{array}{l}\text { 8. Kesesuaian dengan } \\
\text { perkembangan ilmu }\end{array}$ & 3 & 2 & 3 \\
\hline & $\begin{array}{l}\text { 9. Keterkinian fitur (contoh- } \\
\text { contoh) }\end{array}$ & 2 & 3 & 3 \\
\hline & $\begin{array}{l}\text { 10. Kutipan termasa (up to } \\
\text { date) }\end{array}$ & 3 & 3 & 2 \\
\hline \multirow{2}{*}{$\begin{array}{l}\text { D. Menumbuhkan } \\
\text { Keingintahuan }\end{array}$} & 11. Memacu rasa ingin tahu & 4 & 4 & 3 \\
\hline & $\begin{array}{l}\text { 12. Memberi tantangan untuk } \\
\text { belajar lebih jauh }\end{array}$ & 3 & 4 & 3 \\
\hline \multicolumn{2}{|r|}{ TOTAL } & 39 & 38 & 37 \\
\hline \multicolumn{2}{|r|}{$\mathrm{P}(\%)$} & 81,25 & 79,17 & 77,08 \\
\hline \multicolumn{2}{|r|}{ KETERANGAN } & Layak & Layak & Layak \\
\hline \multicolumn{2}{|c|}{ VALIDATOR } & $\begin{array}{l}\text { Trisnendri, } \\
\text { M.Hum }\end{array}$ & $\begin{array}{l}\text { Intan S, } \\
\text { M.Pd }\end{array}$ & $\begin{array}{l}\text { Yanuarti } \\
\text { A, M.Pd }\end{array}$ \\
\hline
\end{tabular}

HASIL UJI KELAYAKAN PENYAJIAN TERHADAP BUKU AJAR LISTENING FOR GENERAL COMMUNICATION 
Instrumen II = Kelayakan Penyajian

\begin{tabular}{|c|c|c|c|c|}
\hline \multirow{2}{*}{ KOMPONEN } & \multirow{2}{*}{ BUTIR } & \multicolumn{3}{|c|}{ Skor } \\
\hline & & Validator 1 & Validator 2 & Validator 3 \\
\hline \multirow{4}{*}{$\begin{array}{l}\text { A. Teknik } \\
\text { Penyajian }\end{array}$} & $\begin{array}{l}\text { 1. Konsistensi } \text { sistematika } \\
\text { sajian dalam bab }\end{array}$ & 3 & 4 & 3 \\
\hline & 2. Kelogisan penyajian & 2 & 3 & 4 \\
\hline & 3. Keruntutan konsep & 3 & 3 & 3 \\
\hline & $\begin{array}{l}\text { 4. Hubungan antarfakta, } \\
\text { antarkonsep, dan antarprinsip } \\
\text { serta antarteori }\end{array}$ & 4 & 2 & 4 \\
\hline \multirow{5}{*}{$\begin{array}{l}\text { B. Penyajian } \\
\text { Pembelajaran }\end{array}$} & 5. Berpusat pada siswa & 4 & 3 & 4 \\
\hline & 6. Keterlibatan siswa & 3 & 4 & 3 \\
\hline & $\begin{array}{l}\text { 7. Kesesuaian dengan } \\
\text { karakteristik mata pelajaran }\end{array}$ & 4 & 3 & 3 \\
\hline & $\begin{array}{l}\text { 8. Kemampuan merangsang } \\
\text { kedalaman berpikir siswa }\end{array}$ & 2 & 2 & 2 \\
\hline & $\begin{array}{l}\text { 9. Kemampuan memunculkan } \\
\text { umpan balik untuk evaluasi } \\
\text { diri }\end{array}$ & 3 & 3 & 3 \\
\hline \multicolumn{2}{|r|}{ TOTAL } & 28 & 27 & 29 \\
\hline \multicolumn{2}{|r|}{$\mathrm{P}(\%)$} & 77,78 & 75 & 80,56 \\
\hline \multicolumn{2}{|r|}{ KETERANGAN } & Layak & Layak & Layak \\
\hline \multicolumn{2}{|r|}{ VALIDATOR } & $\begin{array}{l}\text { Trisnendri, } \\
\text { M.Hum }\end{array}$ & $\begin{array}{l}\text { Intan S, } \\
\text { M.Pd }\end{array}$ & $\begin{array}{l}\text { Yanuarti } \\
\text { A, M.Pd }\end{array}$ \\
\hline
\end{tabular}




\section{HASIL UJI KELAYAKAN KEBAHASAAN TERHADAP BUKU AJAR LISTENING FOR GENERAL COMMUNICATION}

Instrumen III = Kelayakan Kebahasaan

\begin{tabular}{|c|c|c|c|c|}
\hline \multirow{2}{*}{ KOMPONEN } & \multirow{2}{*}{ BUTIR } & \multicolumn{3}{|c|}{ Skor } \\
\hline & & Validator 1 & Validator 2 & Validator 3 \\
\hline \multirow{2}{*}{$\begin{array}{l}\text { A. Sesuai dengan } \\
\text { Tingkat } \\
\text { Perkembangan } \\
\text { Siswa }\end{array}$} & $\begin{array}{l}\text { 1. Kesesuaian dengan tingkat } \\
\text { perkembangan berpikir siswa }\end{array}$ & 3 & 4 & 4 \\
\hline & $\begin{array}{l}\text { 2. Kesesuaian dengan tingkat } \\
\text { perkembangan } \\
\text { emosional siswa }\end{array}$ & 4 & 2 & 3 \\
\hline \multirow{2}{*}{ B. Komunikatif } & $\begin{array}{l}\text { 3. Keterpahaman siswa } \\
\text { terhadap pesan }\end{array}$ & 3 & 3 & 4 \\
\hline & $\begin{array}{l}\text { 4. Kesesuaian ilustrasi dengan } \\
\text { substansi pesan }\end{array}$ & 3 & 3 & 3 \\
\hline \multirow{2}{*}{$\begin{array}{l}\text { C. Dialogis dan } \\
\text { Interaktif }\end{array}$} & $\begin{array}{l}\text { 5. Kemampuan memotivasi } \\
\text { siswa untuk merespon pesan }\end{array}$ & 2 & 4 & 3 \\
\hline & $\begin{array}{l}\text { 6. Dorongan berpikir kritis } \\
\text { pada siswa }\end{array}$ & 3 & 4 & 2 \\
\hline \multirow{2}{*}{ D. Lugas } & 7. Ketepatan struktur kalimat & 3 & 3 & 3 \\
\hline & 8. Kebakuan istilah & 4 & 3 & 4 \\
\hline \multirow{2}{*}{$\begin{array}{l}\text { E. Penggunaan } \\
\text { Istilah dan Simbol/ } \\
\text { Lambang }\end{array}$} & $\begin{array}{l}\text { 9. Konsistensi penggunaan } \\
\text { istilah }\end{array}$ & 3 & 2 & 2 \\
\hline & $\begin{array}{l}\text { 10. Konsistensi penggunaan } \\
\text { simbol/lambang }\end{array}$ & 4 & 2 & 3 \\
\hline \multicolumn{2}{|r|}{ TOTAL } & 32 & 30 & 31 \\
\hline \multicolumn{2}{|r|}{$\mathrm{P}(\%)$} & 80 & 75 & 77,5 \\
\hline \multicolumn{2}{|r|}{ KETERANGAN } & Layak & Layak & Layak \\
\hline \multicolumn{2}{|r|}{ VALIDATOR } & $\begin{array}{l}\text { Trisnendri, } \\
\text { M.Hum }\end{array}$ & $\begin{array}{l}\text { Intan S, } \\
\text { M.Pd }\end{array}$ & $\begin{array}{l}\text { Yanuarti } \\
\text { A, M.Pd }\end{array}$ \\
\hline
\end{tabular}


